\title{
MUUGA VÕI KERSNA? EESTI RÖÖPSETE PEREKONNANIMEDE TEKE JA KADU
}

\author{
Fred Puss \\ Tartu Ülikool ja Eesti Keele Instituut
}

\begin{abstract}
Kokkuvõte. Rööpsete perekonnanimede teke on unikaalne Eestis ja Lätis, kus mõisas pandi 1820.-1830. aastail samale talupojale üks, kirikus aga teine perekonnanimi. Nimede panemise õigus oli mõisadel, kuid kohati võtsid pastorid osa nimede panekust ning muutsid kirikuraamatutes nimesid ka hiljem. Eestis oli üksikuid piirkondi (mõisu), kus rööpnimede hulk oli suurem, nt Ahja mõisas 53\%, Roosna-Alliku mõisa JärvaMadise kihelkonna osas $32 \%$, olles enamasti aga mõne protsendi piires. Võnnu kihelkonnas muutsid vastastikku üksteise nimeloomet mõisavalitsused, kolm järjestikust pastorit ning eriti köster. Pärast üldise perekonnanimepanekuga loodud rööpnimesid oli XIX sajandi teisel poolel ja XX sajandi algul nende tavalisim tekkepõhjus saksastamine, harvem sugulussuhete muutumine (kärgpered, lapsendamised). Kui mõnel pool jõudsid kirikuraamatute nimekujud ka hingeloendisse, siis tavaline see polnud. Sel põhjusel oli ka XX sajandi algul inimestel vallavalitsuse välja antud tsaariaegses passis või iseseisvusaegsel isikutunnistusel üks, kirikuraamatutes teine nimi. Rööpnimed kaotati enamasti riiklike perekonnaregistrite sisseseadmisega alates 1926. aastast ning ametlikustati reeglina sünnikandes leiduv nimekuju. Osal juhtudel tekkisid topeltnimed. Rööpnimed on dokumentides tekitanud segadust ka hiljem.
\end{abstract}

Märksõnad: perekonnanimed, onomastika, antroponomastika, kirikuraamatud, perekonnaseisudokumendid, nimekorraldus

DOI: https://doi.org/10.12697/jeful.2020.11.1.03

\section{Sissejuhatus}

Üldise perekonnanimede (edaspidi pn) paneku kulg Eestis paistab olevat selge. Eesti ajaloo akadeemilise üldkäsitluse järgi pani nimed mõisnik koos pastoriga, talupojad ise kasutasid oma valikuvõimalust vähe ning 1835. a-ks olid kõik eesti talupojad omale nimed saanud. Pärast seda hakkasid need kohe muutuma ning nimede korrastamisel oli kandev roll pastoreil (Rosenberg 2010: 73-74). 
Viimasel veerandsajandil on pn-de ajalooga tegelenud ajaloolane professor Aadu Must, avaldades üldülevaateid pn-de panekust, ning keeleuurijad Kairit Henno ja Enn Ernits, kes on avaldanud kihelkondlikke sünkroonilisi uurimusi üldisest pn-de panekust. Pn-de diakrooniline uurimine on saanud tõuke alles 2016. a alustatud „Eesti perekonnanimeraamatu“ projektist (Kallasmaa jt. 2017, Saar 2019). Pn-de dünaamikat, nende eri kujude põhjuseid ning rööpseid nimesid eri allikates pole uuritud.

Aadu Must (2000: 55-56, 97-98) on pn-de panekut uurides leidnud, et on võimalik välja pakkuda, kes mõjutas mingis paikkonnas nimeloomet enim. Kui kogu kihelkonna nimestikus on ühtlus, siis nähtub Musta järgi selles pastori suunav roll, mõisnike ja mõisaametnike kätt näeb saksapäraste ja muude kultuurnimede suurest osakaalust ning mõne üksiku mõisa nimestiku erinevusest ülejäänud kihelkonnaga võrreldes. Must on ka leidnud, et pastori roll oli väga oluline edaspidises nimede korrastamise töös, vältimaks nimede kordumist kihelkonna piires ning mittesugulaste vahel.

Üldjoontes võib selliste seisukohtadega nõustuda, kuid leidub palju erisusi. Käesoleva töö üks eesmärke ongi näidata erijuhtude kaudu üldise pn-de paneku (1822-1835) kirevust, mis sageli ei võimalda teha üldistusi vaid hingeloendis (edaspidi HL, vajadusel on lisatud aasta: HL26 $=1826$. aasta hingeloend(id); lühendit on kasutatud lihtsuse eesmärgil ka HL süsteemi kuuluvate 1835. aasta perekonnanimede raamatute kohta: HL35) leiduvate mõisa või kihelkonna pn-de loetelu põhjal.

Artikli peaeesmärk on anda ülevaade üldise pn-paneku aegsete rööpsete pn-de tekkimise põhjustest ja nende edasisest saatusest kuni kaotamistaotlusteni. Selleks on esitatud üksiknäiteid mitmelt poolt Eestist, lähemalt on analüüsitud Eestimaa kubermangust Roosna-Alliku mõisa ning Liivimaa kubermangust Võnnu kihelkonna nelja mõisa pn-panekut ja nende arengut. Valik on tehtud põhjusel, et Eestimaa kubermangust on Roosna-Alliku erandlik näide, kuidas üks mõis jagunes kahe kirikukihelkonna vahel, tuues kaasa ühes osas rööpsete pn-de tekke, teises aga mitte. Selline olukord illustreerib ilmekalt rööpnimede tekkepõhjuseid. Liivimaalt on valitud analüüsiks Võnnu kihelkond, kuna see on eriline nii oma ajaloolise nimesüsteemi kui ka üldise pn-paneku osaliste ja ajaraamide poolest. Võnnu kihelkonnas kasutati lisanimena 
sageli püsivat klanninime ${ }^{1}$ ning erinevalt enamikust Eestist jäid reeglina seda nime kandma ka teise perre läinud sulasrahvas, vabadikud jt. Edaspidi vajab väljaselgitamist, kui laialdane ning mis ajani kasutuses oli see tava mujal Eestis. Komme ei piirdu ainult Kagu-Eestiga, näiteks võib tuua sama tava ka Kolga-Jaani kihelkonnast.

Võnnu näide annab võimaluse suhtuda osalise reservatsiooniga eelmainitud üldkäsitluse seisukohta, et nimede korrastamisel oli kandev roll pastoreil. Võnnu näitel tegelesid nii mõisavalitsused, pastor kui ka eelkõige köster nimede vastastikuse korrastamisega ning seda massiliselt veel 1850. aastail ehk üle veerandsaja aasta pn-de paneku lõpust hiljem.

Artikli eesmärk on anda ka allikaõpetuslikke lisandusi rahvastikuloo ning antroponomastika uurimise põhiallikate (sh onomastika andmebaasi) edaspidiseks kasutamiseks, kuna rööpnimed on põhjustanud seni segadust ja vääritimõistmist nii ajalooharrastajate kui ka teadlaste hulgas. Hulgalised näited teenivad ka eesmärki juhtida tähelepanu liigkergekäeliste järelduste tegemise võimalusele konkreetse nime tekkelugu käsitledes. Samuti avab allikate tutvustus ja analüüs tausta, mida tuleb arvestada nende kasutamisel, eriti arvulisel analüüsil (nt Poka mõisa HL ja personaalraamatu andmed on väga halvasti võrreldavad, kuna paljud Poka pered on PR-s kirjas Mäksa mõisa all ja vastupidi).

Asetamaks rööpsete pn-de tekke ning saatuse Eestis laiemasse konteksti, on antud ka ülevaade sarnastest juhtudest mujal maades. See võimaldab näidata selliste nimede tekke puhul Eesti unikaalsust, nende juriidilise staatuse puhul aga Eesti eeskuju võtmist teistest maadest, eriti Saksamaast. Artikli maht ei võimalda põhjalikumalt käsitleda kõiki rööpsete pn-de tekkimise põhjuseid Eestis. Neid on mainitud näidetena, asetamaks uuritava teema nende konteksti.

Artiklis on kasutatud termineid järgmiselt. Lisanimi (ingl byname) - eesnime ees kasutatav nimi, mis võis olla tuletatud klanninimest, perenimest, kohanimest, talunimest, hüüdnimest, ametinimetusest vmt. Klanninimi e sugukonnanimi (clan name) üldise perekonnanimede paneku (1822-1835) eel eksisteerinud ja ka selle järel kasutatud tõenäoliselt ühe sugukonna meesliinis päritav lisanimi. Omane eelkõige Kagu-Eestile. Klanninime tuvastamiseks on vajalik genealoogilise meetodi kasutamine. Perenimi (farm household name) - üldise perekonnanimede paneku eel eksisteerinud ja ka selle järel kasutatud (talu)majapidamise liikmete ehk talupere ühine lisanimi (sageli kattus talunimega). Talunimi (farmstead name) - konkreetse kohaga seostatava talumajapidamise nimi; enne kohale kinnistumist oli tegu perenimega, mida kasutati ka talunimena. Perekonnanimi (surname, family name, last name) - Eestis üldise perekonnanimede paneku ajal talupoegadele fikseeritud päritav nimi; vabadel inimestel esines ka varem. 


\section{Historiograafia. Allikad. Meetodid}

Rööpsete pn-de olemasolu on nimeuurijatest ühe esimesena maininud Matthias Johann Eisen, leides, et tänini leidub mõnel isikul kahesugune nimi: üks on vall a ra a ma tu tes, teine kirikukirja de $s^{2}$. Tema arvamus selliste eri nimede tekkimisest ei ole küll usutav: mõisaraamatutes saanud vallaelanikud priinimede osaliseks 1826 . a ning kirikukirjades alles 1833. a või hiljem ning talupojad andnud kirikuõpetajale ise teise priinime üles, kui neile oli mõisas kirja pandud. (Eisen 1921: 15)

Hiljem on rööpsete pn-de olemasolu samuti vaid põgusalt mainitud (nt Must 2000: 57), kuid eraldi uuritud neid pole. Olulised pn-alased uurimused (Rajandi ja Tarand 1966a, Rajandi ja Tarand 1966b, Tiik 1987, Henno 2000) isegi ei maini nende olemasolu.

Alles siinkirjutaja (Puss 2016: 33) on kokkuvõtlikult käsitlenud rööpsete pn-de tekke põhjuseid, omistades selle küll ainult pastorile. Evar Saar (2019: 207-209) on Räpina kihelkonna pn-de teket uurides välja toonud mitmete rööpsete nimede olemasolu samadel perekondadel ning võrrelnud põgusalt ka eri allikate nimede kattuvust.

Põhiallikatena kasutati siin uurimuses pearaha- ja nekrutikohustuse arvestamiseks koostatud hingeloendeid (revisjonilehti) aastaist 18261858 ning kirikuraamatuid (eelkõige personaalraamatuid ja meetrikaraamatuid, kuid ka armulaualiste nimekirju). Võrreldavate HL-te ja personaalraamatute (edaspidi PR, vajadusel lisatud algusaasta: PR34 = 1834. aastal alustatud personaalraamat(ute komplekt)) kohta koostati nimeregistrid, leidmaks kattuvaid ja lahknevaid nimesid. Hingeloenduste lõpetamise (1858) järgsest ajast kasutati hingekirjutuse süsteemi järgmist dokumendiliiki, alates 1874 koostatud vallaliikmete nimekirju. Nende põhjal anti välja passe (reisimiseks või mujal elamiseks) ning seetõttu leiame kirikuraamatutest mõnikord rööpsete pn-de juures märkuse ,passi järgi“, st selline oli isiku nimi vallaliikmete nimekirjades. Nimekirju on kasutatud siin töös vaid üksikjuhtumite jaoks. Esimesest iseseisvusajast on samal eesmärgil kasutatud elanike nimekirju ning perekonnaseisudokumentatsiooni (perekonnaregistrit, selle lisatoimetusi, perekonnaseisuakte).

Kaldkirjas on täpne tsitaat kirjandusest või allikast, millele on viidatud. Jutumärkides on autori tõlge või parafraseering. 
Võnnu kihelkonnast analüüsitud põhiallikate (HL26, PR42, meetrikad) iseärasusi ja sellest tingitud töö täpsemat metoodikat on lähemalt kirjeldatud peatükis 6.2 ning Roosna-Alliku mõisa puhul peatükis 7, et anda parem taust järgnevaks analüüsiks.

Teksti viidetega koormamise vältimiseks pole reeglina viidatud PR ja HL andmetele, välja arvatud juhud, kui andmed on raskemini leitavad või viidatud on mitte pn-dele, vaid märkustele.

Töös on kasutatud võrdlev-ajaloolist meetodit Eestimaa ja Liivimaa kubermangus toimunud protsesside ühisjoonte leidmiseks. Konkreetsete nimede analüüsimisel on kasutatud genealoogilis-biograafilist meetodit. Rootsi pn-de ühe esimese teadusliku uurija Gudrun Utterströmi sõnul ilma selle meetodita ,ei ole võimalik selgitada nime andmist ning levikut" (Utterström 1985: 14). Soome onomastikadoktor Sofia Kotilainen on väljendanud seisukohta, et „on vajalik kombineerida genealoogilist ja kollektiivset biograafilist uurimismeetodit /.../, kui soovitakse kasutada kõiki võimalusi, mida pakuvad (päritavad) isikunimed ajaloolises ning lingvistilises uurimuses. /.../ Pikaajaline ning süsteemne empiiriline uurimus võimaldab meil ka küsimuse alla seada mõningaid varasemaid oletusi, mida on ajaloolises onomastikas peetud iseenesestmõistetavaks" (Kotilainen 2011: 44). Siin töös on meetodit kasutatud samade inimeste kohta eri allikaliikides toodud pn-de võrdluseks.

\section{Rööpsed perekonnanimed väljaspool Eestit}

Ühe inimese nimevariandid on varieerunud läbi ajaloo ning seda mitte ainult õigekirjutuse või tõlkimise tõttu, vaid ka sisu poolest. Vana-Roomas oli polüonüümia ehk rööpnimelisus levinud esialgu kõrgklassides ning lihtrahvas hakkas seda imiteerima, kasutades eelkõige kahte lisanime (cognomen) (Solin 2017: 249).

Pn-de puhul on varieerumise põhjuseid mitmeid. Üks varasemaid neist on paljudes maades pn-de ning lisanimede vaheldumine, st pn-d polnud veel juurdunud ning inimesi võidi tuvastada vahelduvalt ka lisanimedega.

Aadlike hulgas on pn-de vahetus olnud eriti vanemal ajal sagedane. Lisanimed on vaheldunud valduse (elukoha) nimega. Nt 23 Austria ja Baieri krahvisuguvõsa kandsid keskajal 226 eri perekonna- ehk lisanime 
(Zuname) (Bach 1978: 104). Saksa XVI sajandi genealoogilised uurimused näitavad, et ühe suguvõsa liikmed võisid kanda poolt tosinat eri pn (Heydenreich 1913: I, 292).

Ka Eesti-, Liivi- ja Kuramaa aadlisuguvõsadest on teada rööpnimesid: Hoyningen genannt Huene, Osten genannt Sacken, Vietinghoff genannt Scheel jt. Neist viimane on topeltnimena teada juba aastast 1307 (Mühlendahl ja Hoyningen gen. Huene 1973: 185). Aadeldamisel aadlinime saamise näol on reeglina tegu nimemuutusega, mitte rööpnimedega. Näiteks Olaus Swebilius sai 1684. aastal Rootsi aadlikuna nimeks Adlerberg (Elgenstierna 1925: 19). Harva kasutati aadeldamise järel mõlemat nime rööpselt, sel juhul tuleb neid pidada pigem kirjutaja sooviks inimest võimalikult täpselt tuvastada (Ryman 2002: 320-321).

Saksa kodanikusuguvõsades on pn-d vaheldunud sageli majanimega. Ühe Frankfurdi patriitsiperekonna liikmed, kes kandsid algul maja järgi nime Zum Schnabel, said hiljem oma elumajade järgi nimedeks Zum Salzhaus, Zum Eßlinger, Zer Schuren jt (Bach 1978: 105). Johannes Gutenbergi perekonnanimi oli tegelikult Henne Gensfleisch ning meile tuntud nime võttis ta maja järgi, mis kandis tema ema pn (Heydenreich 1913: I, 291).

Saksa talupojad kandsid XX sajandi esimesel poolelgi sageli pn-na talunime. Elukoha vahetuse või meeste mujale abiellumisega nimi muutus. Sellise nimevahetuse keelas Preisi siseminister oma 1907. a määrusega. Saksa 1875. a perekonnaseisu- ja abieluseaduse alusel juhendati perekonnaseisuametnikke kirjutama talunime alusel võetud nime pn järele märkusega auch genannt 'kutsutud ka' (nt Nobbeling gen. Osterhof) ning osas piirkondades anti selle kasutamise õigus vaid taluomanikule ja tema abikaasale. (Bach 1978: 106, Loos 1973: 106). Saksa keeles ongi seda tüüpi nimesid nimetatud Genanntname, Vulgoname jm.

Ungari keeleala eri piirkondadest XVIII sajandil juba koos pn-dega Serbiasse asunud russiinide puhul on kasutatud lisaks ametlikule, sageli ungarikeelsele pn-le kuni kaheksat, ungari-, serbia- või russiinikeelset mitteametlikku lisanime (cognomen), mis eristavad suguluseta perekondi teineteisest (Fejsa 2013: 28-29). Kuigi tegu on pn funktsiooniga nimega, võib neid mitteametlikkuse tõttu pidada pigem hüüdnimeks.

Mitmekeelsetes piirkondades on levinud nimede mugandamine keelte vahel. Sorbide hulgas on sagedased nimede mitu foneetilis-ortograafilist varianti, kas häälikuliselt mugandatuna (Krawc $\sim$ Krautz) või 
ka tõlgituna (Kowar Schmidt) (Wenzel 2004: 706). Alam-, kesk- ja ülemsaksakeelsed pn-d varieeruvad suurel määral, võides näida tõlgituna eri dokumentides eri nimedena: Niemann $\sim$ Naumann $\sim$ Neumann, Bachmann $\sim$ Beckmann, Fuchs $\sim$ Voß (Wenzel 2004: 716), kuigi nende tähendus on sama. Nimede tõlkimise kaudu rööpvariantide tekkimine ongi tavapärane kas teisele keelealale elama asumise või muukeelse administratsiooni puhul.

Põhja-Ameerikas tekkisid rööpsed pn-d (dit-nimed) eelkõige Prantsuse armeega XVIII sajandil liitunud sõduritele. Nt Étienne Gourdon valis endale sekundaarseks nimeks Vadeboncœur 'go with a good heart' ning tema järeltulijad võisid kasutada emba-kumba pn. (Hanks 2003: 124).

Dit-nimede komme kestis XIX sajandini ning nimede koos kasutamisel ei oldud järjepidevad, neist võis esineda emb-kumb eraldi või ka mõlemad koos (Geyh et al. 2002: 14). Dit-nimed esinesid ka Prantsusmaal. Üks tuntumaid selliseid oli Alexandre Gustave Bonickhausen dit Eiffel (1832-1923), kelle Reinimaalt 1710. a paiku Pariisi emigreerunud Bönickhausenite suguvõsa võttis nime Eif(f)el oma endise kodumaa mälestuseks, kuid alles 1879. a-st kandis Gustave ainsat ametlikku pn Eiffel (Lemoine 1988: 14).

Rööpseid pn-sid tekitasid ka juriidilise ruumi muutused. LõunaPoola Chęciny linn läks 1795. a kolmanda Poola jagamisega Austria alla, kus elavatelt juutidelt nõuti pn-sid 1805. a. Neljanda Poola jagamise järel aastal 1815 läks piirkond Venemaa alla ning seal nõuti juutidelt pn-de kandmist alates aastast 1821 . Tulemuseks oli, et osa perekondi või mõne perekonna osa liikmeid pöördusid tagasi oma vanade nimede juurde või võtsid hoopis uued nimed ning tekkisid nimekujud, nagu nt Manela v Kwart (v = ladina k vel 'ehk; samuti') (Eisenberg Davis 1996: 5).

Soome puhul on Viljo Nissilä maininud kahe või enamagi pn kasutamist XVI sajandil, kuid Sirkka Paikkala on selle väite kummutanud põhjusel, et toodud näited polnud põliste pn-de aladelt ning nimed olid segu talu- ja pn-dest (Paikkala 2004: 58). Paikkala (2004: 478-489, 497-501, 553) on analüüsinud eri piirkondade pn-kasutust kirikuraamatutes XIX sajandi teisel poolel ja XX sajandi algul ning leidnud rööpsete pn-de (rinnakkaisnimet) osakaalu olevat 0-8,6\% juhtudest, olles enamasti $0-1 \%$, üle selle vaid paaris Lääne-Soome pn-süsteemi alal paiknevas kihelkonnas ning kaardiväesõdurite puhul. Rööpsete 
pn-de esinemise põhjused Soomes on Paikkala (2004: 480, 484-485, 489, 501-502) järgi enamasti nimevahetus (soomestamine vm muutmine), kohati ka eri nimesüsteemide (talunimi-lisanimi, idapoolsed pn-d, sõduri- ja käsitöölisnimed) segunemine. Seetõttu on rööpnimede esinemise põhjused Eestist erinevad, lisaks on Paikkala analüüsinud vaid kirikuraamatuid ehk ühte liiki allikaid, tema toodud nimemuutmiskuulutuste näidetest selgub, et rööpnimed võisid esineda just eri allikates (Paikkala 2004: 528).

Ülaltoodust järeldub, et paljudes nimesüsteemides on levinud enamasti inimeste endi valitud või neile lisanimest tekkinud rööpsed pn-d, olgu need elukoha järgi, tõlgitud või vabalt moodustatud, samuti olid nad kas mitteametlikus või poolametlikus staatuses. Segunenud on lisaja perekonnanimed, mille eristamine on nimeuurijatele sageli raskusi valmistanud. Nimesüsteemide korrastamine algas peamiselt alles XIX sajandil (vt lähemalt ptk 8).

Eestiga sarnast süsteemi, kus eri ametiasutused (kui nimetada mõisa ja kirikut tinglikult nii) annavad samadele inimestele eri sisuga ametlikud pn-d, pole autor kohanud mujal kui Lätis, kus küll sellekohased uurimused puuduvad.

\section{Eesti rööpsete perekonnanimede õiguslik taust}

Liivimaal sätestas pn-de paneku 1819. a talurahvaseaduse $\S 11$, mille järgi pidi vabastatavatele talupoegadele andma (beilegen 'juurde lisama; omistama; andma') pn-d (Zunamen), mida ei tohi vahetada muidu kui vaid kõrgema võimu (Obrigkeit) loal; lisaks pidi need nimed kirja pandama vabastatavate talupoegade nimekirjadesse (LBV: § 11). $\mathrm{O}$. W. Masing kasutas oma tõlkes nime andmise kohta väljendit „enesele liignime andma" ning lisas omalt poolt algtekstis puuduva nõude, et seda ei tohi ärraheita (LTS 1820: 9). G. A. Oldekop ja L. W. Moritz oma tõlkes kasutasid väljendit „,väärnime võtma“ (LMS 1820: 9). Rööpnimede puhul on oluline seaduse $\S 12$, mis ütleb, et talupojad pannakse pn-ga kirja hingeloendisse ning kirikuraamatusse (in den Revisionslisten mit seinem, auch in das Kirchenbuch einzutragenden Zunamen verzeichnet) (LBV: § 12). Masing ja Oldekop pidasid vajalikuks tõlkides täpsustada, et kirikuraamatusse kirjapanek toimub mõlemasse kohta „ühe ja sama nimega“ (LTS 1820: 10, LMS 1820: 10). 
Talupoegade pärisorjusest vabastamise ning neile pn-de andmise materjale on säilinud väga harva ning eri asutuste arhiivifondides: Viljandi kihelkonna kohta kihelkonnakohtu fondis (EAA.932), Halliste, Karksi, Saarde (sh Häädemeeste) kohta samuti kihelkonnakohtu fondis (EAA.931), veidi rohkem Saaremaalt Liivimaa HL-te fondis (EAA.1865). Üksikuid nimekirju leidub ka vallakohtute protokollides (vaid Abja, Pati, Pöögle ja Vana-Antsla puhul). Üsna hästi on säilinud 1826. a HL-d, kus on pn-d juba kõigil talupoegadel fikseeritud.

Seaduse ja kubermanguvalitsuse käsu järgi pidi nimepanek Liivimaal olema korraldatud mõisa poolt, kuigi sõjakuberner Paulucci palus Liivimaa ülemkonsistooriumilt, et nimede panemine ka pastorite tähelepanu all oleks (R[eiman] 1898: 1). Mõnes Liivimaa piirkonnas (Kanepis juba varem, aga ka Vastseliina, Räpina, Põlva, Rõuge ning Muhu kihelkonnas ning võimalik, et mujalgi) andsidki pn-d eelkõige pastorid, mitte mõisavalitsejad (Puss 2016: 34-35). Räpinas kattuvad PR ja HL nimed enamasti, kuid mitte täielikult. Sellest on Evar Saar (2019: 208-209) järeldanud, et pastor tegi nimede panekul eeltöö ning nimemoodustamissüsteemi lõi tema, kuid HL26-sse jõudsid nimed sageli muudetud kujul.

Eestimaal toimus üldine pn-de panek 1834.-1835. a. Eestimaa kuberner kirjutas oma plakatis (saksa keeles nr 75, 26.10.1834 ja eesti keeles nr 97, 14.12.1834) nimede paneku põhjusena, et kindralkuberner von der Pahlen kirjutas talle, et siseminister temale teatanud järgmist: Lutterusse ussorahwa üllem Konsistorium temma käest pallunud, et nende hingeramatude pärrast, mis kirriku öppetajad omma koggoduste hingedest peawad teggema, tallorahwale Eestimaal käsko saaks antud, et ennestele ühhed jädawad liignimmed (sugguseltsi nimmed) peawad pannema, mis sündsad ja makele-murde järrel on. Siseminister nõudis ka nimede kirjutamist käimasoleva VIII hingeloenduse lehtedele. Kuna aga loendus oli juba lõppemas, lasi kindralkuberner kokku kutsuda riigi ja kiriku esindajate nõupidamise, mille alusel kindralkuberner kinnitas pn-de paneku korra. Selle esimene punkt määras, et nimed paneb mõisavalitsus. Kiriku osa nimepanekul kord ette ei näinud. (RA29, L 30-31p, $34 \mathrm{p}-35 \mathrm{p})$

Kuberneri selgitusest paistab välja, et tõuge nimede panekuks tuli kiriku pöördumisest, saamaks nimesid uue vormi järgi nõutavatesse kirikuraamatutesse kanda. Tõepoolest, Venemaa luteri kiriku 1832. a seaduse (ПС3 II, nr 5870, 28.12.1832) § 205 jj ning lisas lit. $A-G$ 
olevad meetrikaraamatute, leeritatute nimekirja, armulaualiste nimekirja, abiellunute pearaamatu ja personaalraamatute andmete koosseisud ja vormid nõudsid pn (venekeelses originaalis фамилія) kirjapanemist alates vormide kasutusele võtust 1834 . Nimede panek jäi aga kohalike eeskirjade kohaselt hoopis mõisavalitsuste otsustada.

Vene õigeusu meetrikaraamatutesse tuli nõue pn-sid (фамилия) kirja panna 1838. a-st, varem ei määranud meetrikate vorm andmete koosseisu nii täpselt, vaid märkima pidi, ,kellele laps sündis“ ( $у$ кого кто родился) (Statina 2010: 20).

Samas ei toonud 1838. a nõue kaasa üldist pn-de panekut Venemaal ning meetrikaraamatute täitmisel jätkati pn puudumisel vaid ees- ja isanime kasutamist. Selles valguses tundub plakatis toodud põhjendus pn-de panekuks Eestimaa kubermangus olevat pigem ettekääne või lihtsalt tõuge, et saada selles küsimuses Liivimaale sarnaseks.

Nimepanekut Eestimaal uurinud Leo Tiik (1987: 85) on välja toonud mõned pn-de parandused kihelkonnakohtute poolt, kuid pole käsitlenud kirikuõpetajate osa selles. Üks unikaalne kaasaegne sissekanne leidub Järva-Madise koguduse PR34 tiitellehel pastor Ferdinand Ludwig Hörschelmannilt (RA5:2, autori tõlge):

Need mitmed muudatused, mida eelseisvate pn-de puhul oli vajalik teha, ning mida ei saa pidada [õigekirjutuslikeks] parandusteks, tulevad sellest, et need pn-d anti kõigepealt üles talupoegade poolt suuliselt ja kanti ka nii sisse, mille kohta käib eeltoodud märkus õigekirja kohta. Kui seejärel kogukonnakohtute (=kihelkonnakohtute) juures koostatud talupoegade pn-de nimestikud kirikuni jõudsid, olid nimed [algsetest] tugevasti kõrvale kaldunud ning nii vähegi kui ka mõisade poolt esitatud nimede nimekirjad olid eesti keelega tuttavad, andsid nad tunnistust kohatutest ja ennekuulmatutest naljatlemistest, mida mõne antud nime kallal tehti. Nii pidi [kirikuõpetaja poolt] sisse viidama mitmeid parandusi ning suure osa mitte-eesti nimedest aktsepteerima, kuna need nimekujud olid nü̈̈d omandanud õigusliku aluse.

See selgitab allpool käsitletud Roosna-Alliku rööpsete pn-de tekke põhjuseid ning annab ka kinnituse, et kirikuõpetaja tegeles nimede muutmisega alles kõige viimases järjekorras. Nagu ta isegi tunnistab, ei olnud tal juriidilist õigust nimede muutmiseks, järelikult lähtus ta vaid moraalsetest tõekspidamistest. 


\section{Rööpnimede levik Eestis}

Rööpsed pn-d ei olnud vaid mõne piirkonna omapära, vaid neid leidus üle Eesti. Kohati oli neid tavapärasest enam (vt alltoodud RoosnaAlliku ja Võnnu näited), kuid üksikuid näiteid leidub kahtlemata igast kihelkonnast. Nende teke jääb valdavalt pn-de paneku aega, kuid neid tekkis ka hiljem.

Laiuse kihelkonnas ja mõisas kandis üks pere 1823-1836 PR järgi pn Kerstem Kersten (RA24:44, 1k 85; RA25:70, 1k 159), HL järgi Sehr (RA20:44, L 59p), alates 1835 peetud PR-s aga hoopis Kask (Sehr) (RA26:85, L 151). Osa Laiuse mõisa peresid kandsid mõlemas allikas vaid pn Sehr, seega ei olnud kõigil selle nime kandjatel mitu pn.

Ambla kihelkonnas Järvajõe mõisas kandis HL järgi Trilli nime kandnud pere (RA14:101, L 101p) kirikuraamatutes nime Trilljärv (RA8:271).

Vabadik Jüri sai Elistvere mõisa HL26 järgi pn-ks Romet, Äksi koguduse PR järgi aga Rommet Masik (RA22:32, L 32p; RA12:35, L 38). Tema poeg Tõnu elas eraldi ning sai HL26 järgi nimeks Masik, PR järgi aga Masik Romet (RA22:24, L 24p; RA12:41, L 43). HL-s jäidki nad kandma eri nimesid, vastavalt Romet ja Masik. Kirikuraamatutes muutus ka Tõnu ja ta pere nimi Rometiks, kuid sellele lisati hiljem alias Masing (RA34:148, 1k 1291). Tõnu pojapoeg Rudolf Eduard kandis vallaliikmete nimekirjade põhjal koostatud väeteenistuskohustuslaste nimekirjas aastal 1895 nime Мазингъ (онъ же Рометъ) (RA30:206, L 107p). Kuigi Rudolf Eduardi sünnikandes on vaid perekonnanimi Romet (PR-s aga „Masing, ka Romet"), kanti tema perekirjale Tallinna perekonnaregistris (vt ptk 8) mõlemad nimekujud: Romet (Masing) (TLA7, L 903). Tema tütre Helmi sünnikandes on aga „Masing, kutsutud ka Romet" ning nii sai tema perekirjale nimeks Masing, nimetatud Romet (TLA6, L 435). Kui oleks lõpule viidud idee hakata isikutunnistusi andma vaid perekonnaregistri põhjal, oleks isa ja tütar kandnud eri pn. Edaspidi kasutas see pere vaid Masingu nime, Rudolfi vend Karl aga topeltnime Romet-Masing (RA50).

Üldisest perekonnanimede panekust hilisema rööpnimede tekke põhjus võis olla inimese enda, kooli või kirikuõpetaja algatus nime muutmiseks, sagedamini eestipärasest saksapäraseks (vrd ptk 8 Rajandi seisukohta). Helilooja Konstantin Türnpu (1865-1927) vanem vend sündis aastal 1863 nimega Tirnbaum, helilooja ja ta noorem õde sündisid 
nimega Türnpu, nagu oli nimi HL-s ja varem ka kirikuraamatutes. Nähtavasti toimus nimemuudatus saksastamise eesmärgil ning kinnistus perekonnale 1880 Tallinna asudes, kuna siis kirjutati see juba esikohale: Tirnbaum (al. Türnpu), kohati ka Türnbaum. Hingekirjutuse süsteemis (Tallinna tsaariaegsetes perekirjades) jäi nimeks Türnpu. Helilooja ise pöördus selle juurde tagasi juba varakult ka kirikuraamatute järgi ning seda on ekslikult seostatud nime eestistamisega, tema vend jäi aga Türnbaumi nimekuju juurde ning tema isanimigi saksastati Jaanist Johanniks. (RA16:108, L 107p; RA1:136, :191, :247; TLA9:185, L 279p; TLA1:82, L 839; TLA11:55, lk 109; TLA10:340, L 393p)

Samuti võis rööpnimede tekkepõhjuseks olla sugulussuhete korrastamine, nt kasvandikuks võtmise või lapsendamise puhul. Puurmani mõisa talupoja Joosep Saealle naise Madli enne abiellumist sündinud poeg Jüri (1820-1869) kandis nii HL-s kui ka kirikuraamatutes nime Saealle. Jüri poeg Jaan (1852-1917) hakkas aga Tartusse elama asununa nimetama ennast Kosteri nimega (nennt sich Koster), tõenäoliselt soovist mitte seostada ennast võõrasisa nimega või soovist seostada ennast tegeliku isa (perekonna) nimega. Sellest kujunes vähemalt osas dokumentides ajutine rööpnimepaar Саэелла (онъ же Костеръ), mis aga hiljem tõenäoliselt kadus. (RA27:12, L 9p; RA11:111, L 90-90a; RA35:20, L 19; RA19:61, L 59p; RA28:21, L 18p)

Genealoogilis-biograafiline meetod aitab välja selgitada rööpnimede kasutuse kronoloogia ning selle alusel saab järeldada nende tekke põhjust.

\section{Rööpnimed Võnnu kihelkonnas}

\subsection{Lisa- ja perekonnanimed kirikuraamatutes}

Rööpnimede tekke selgitamiseks Võnnu kihelkonnas tuleb olla tuttav ka sealse omapärase lisanimesüsteemiga. Kuigi teema vajab täpsemat uurimist, võib teha mõningad üldistused. Võnnu kihelkonnas olid eesnime ees lisanimedena tihti kasutusel põlised sugukonna- ehk klanninimed, mis olid püsivad juba hiljemalt XVI sajandi lõpust ning mis mõjutasid ka talunimede kujunemist. Pere ühest talust teise asudes ei muutunud nimi mitte perel, vaid talul. Sarnast süsteemi võib kohata ka näiteks Räpina kihelkonnas (Saar 1999, Saar 2008), kuid XIX sajandi alguseni oli see levinud mitmel pool mujalgi. 
Ülle Tarkiainen on järeldanud, et külatalude nimedest võib rääkida alles XIX sajandi 2. veerandist alates, mil talunimesid hakati peremehe lisa- ja eesnimest eraldi kirja panema ning lisanimed kadusid käibelt pn-de panemisega, muutudes talunimedeks (Liitoja 1992: 36-37). Hajatalud olid Tarkiaise hinnangul oma tervikliku maa-ala tõttu püsiva nimega juba XVII sajandi algul ning nende nimi püsis ka elanike vahetuse korral ja tühjaks jäämise järel, samas kui XVII sajandil tekkinud hajataludel eriline talunimi puudus ja kasutati peremehe nime (Tarkiainen 2000: 76-78). Põhja-Tartumaa puhul on Tarkiainen (Liitoja 1992: 41) leidnud, et vahemikus 1688-1758 jäid muutumatuks vaid veerand, vahemikus $1782-1858$ aga 3/4 hajatalude nimedest.

On leitud, et Räpinas olid mõned kohanimed samad XVI ja XIX sajandi allikates (Annist 1971: 17) ning seostatud seda XVIIXVIII sajandi sõjategevusest kõrvale jäämisega (Tarkiainen 2000: 79). Kuigi viimase mõju oli kahtlemata oluline, on tõenäolisemalt tegu püsivate klanninimedega, mitte kohanimedega. Kahtlemata on paljude piirkondlike erisuste tõttu raske teha üldistust isegi küla- ja hajatalude nimede järjepidevuse kohta ning pere- ja talunime suhted vajavad jätkuvat uurimist.

Võnnu kihelkonnas oli üldisel pn-de panekul tegevad mõisaametnikud ja pastor paralleelselt. HL26-s fikseeritud pn-de ühtlus varieerub tugevalt, seetõttu võib arvata, et sellega tegeles iga mõis omaette, kuid pastor võis anda üldiseid soovitusi.

Aastail 1796-1846 oli Võnnu koguduse pastor Eduard Philipp Körber (1770-1850). Ta oli rahvasõbralik estofiil, muinsusteuurija ning tartu keele pooldaja. Tema tegevus talurahvasõbrana ning pn-de paneku mõjutajana Võnnu kihelkonnas väärib lausa eraldi käsitlust. Siinkohal olgu esitatud ülevaade vaid tema nimekasutusest meetrika- ja personaalraamatutes.

Enne 1834. a meetrikaraamatute vormi, milles seati sisse koht ka pn-dele, Körber pn reeglina ei kasutanud. Vaid väljaspoole suunatud dokumentides kasutas ta kuju $N_{e}$ (eesnimi) $+N_{p}$ (perekonnanimi või pn funktsioonis lisanimi) juba jaanuaris ja veebruaris 1823 kohtutele saadetud kirjades: Jaan Tennosar ja Jaan Semmel (RA43, 1k 70-71). Tõenäoliselt olid needki lihtsalt tagurpidi pööratud lisa- ja eesnimi, nagu Körber kasutas hiljem.

Uue vormi järgi peetud 1834. a abielumeetrika algeksemplari algusesse kirjutas Körber peigmeestena Prehhi Petri Jaan, Pulli Hindrik, 
Pijri Mick jne, sellest järgmise aasta algul konsistooriumi jaoks ärakirja tehes aga kirjutas ta samad nimed Jaan Prehhi, Hinrich Pulli, Mick Piir. Aprillist 1834 hakkas ta ka algeksemplari kirjutama vormis $N_{e}+N_{p}$, sellest küll aeg-ajalt hälbides. Genitiivsest lisanimest on ta kord teinud nominatiivse pn (Prakli $>$ Prakel, Semmeli $>$ Semmel, Musta $>$ Must), kord jätnud selle genitiivsesse vormi (Otsa, Laari, Hanni). Võrdlusel hilisemate raamatutega (nt köster Hollmanni koostatud PR55, RA40) selgus, et genitiivsest lisanimest perekonnanime moodustamisel oli ka pärast Körberit kasutusel nii nominatiivne kui ka genitiivne vorm ning seda üsna juhuslikult. Näiteks Kutsari $>$ Kutsari, aga Molloka $>$ Mollok.

Körberi peetud sünnimeetrikas on samuti alates juunist 1834 nimed enamasti ümber pööratud ning kasutama hakatud vormi $N_{e}+N_{p}$. Sageli on lapse nimi vormis $N_{e}+N_{p}$, isa nimi $N_{p}+N_{e}$. Surmameetrikas on kasutatud mõlemat vormi, laste puhul on nende isanimi vormis $N_{p}+N_{e}$, täiskasvanute puhul pigem $N_{e}+N_{p}$. Lisanimest erinevat pn on kasutatud peamiselt teiste koguduste liikmete või vabade inimeste puhul, nt 1840 abiellusid Haaslavalt pärit Kitse Jüri poeg Jacob Schwalbe ja Kurista vanavaba Johann Koltberg'i tütar Miina. Aasta hiljem abiellus siiski meetrika järgi ka kohalik peremees Türa Jacob Freijberg, kes kandis seda pn ka HL-s.

Meetrikates Körberi poolt kasutatud pn-de funktsioonis lisanimedest suur osa ei jäänud pärast 1840. a-id enam pn-na kasutusse, sest nende asemele tulid teised (vt allpool).

Körberi sisse seatud 1806-1839 peetud PR-s (RA36) ei leidu pn-sid peale mõningate üksikjuhtumite (eelkõige sisserännanute nimed). Näiteks Räpinast sisserännanud on Körber erandlikult kirjutanud pn-ga: 1832 tulnud Jago Jagob Jagoberg ja 1833 tulnud Tilga Mik Tilgand. Huvitav on seejuures, et Jaago Jakobil on perekonnanimi hiljem maha tõmmatud, kuigi seda nime kandis ta Räpinas nii PR kui ka HL järgi.

Usutavasti Körber samastas lisa- ja perekonnanimesid ning ei pidanud uute pn-de andmist vajalikukski, arvates, et tema kihelkonna talupoegadel olid need juba olemas. Selline teguviis pani aluse rööpsete pn-de tekkele Võnnu kihelkonnas, sest mõisavalitsused panid talupoegadele aastail 1822-1826 pn-d, kuid see oli alles segaduste algus.

Körber oli Võnnu pastori ametis 1846. a-ni, pidades mõningaid kirikuraamatuid veel tolgi aastal nähtavasti oma Randu läinud poja Louis Körberi (1808-1892) asendajana, kuid aktiivsest pastoritegevusest taandus ta 1836. a. Sellest aastast oli Louis Körber Võnnu 
koguduse adjunktpastor, täites tegelikult pastori ülesandeid suurelt osalt üksi. 1846-1853 oli ta pastor Rannus ning 1853-1880 Rõngus.

L. Körber võttis 1842 kasutusele uue PR (RA37, RA38, RA39), mida peeti aastani 1855 . Selles on andmed esitatud sarnaselt 1806-1839 peetud raamatutele mõisade ja külade kaupa, järjestatuna lisanimede alusel. Osa pn-sid on lisaks lisanimedele kohe sisse kantud, leidub mõisu (nt Kurista, Sarakuste), kus enamik pn-sid ongi kirja pandud kohe ning kui neid ei leidu, on pn samastatud lisanimega (st Mäkalla Jaan = Jaan Mäkalla). Pered on tähestiku järjekorras ning nende vahele samas tähestikus on kirjutatud ka nende sisserännanute andmed, kellel oli kirjas vaid pn, aga mitte lisanimi, näiteks Norman Wilhelm või Rautsep Jakob. See kinnitab lisanimede mõistmist pn-dena. Lätist pärit vanavaba Michelson Adam on saanud märkuse, et ta oli „varem Klaus“ (RA37:123, L 140), mõeldes selle all nähtavasti tema lisanime.

Üks pn fikseerimise puhul oluline, kuigi teadaolevalt ainukordne märkus leidub PR42-s Kooskora perede puhul. Sinna on L. Körber kirja pannud: Alle Kooskors haben den Zunamen Koor gewählt 'kõik Kooskorad on valinud pn-ks Koor' (RA37:7, L 5). Termini puhul on huvipakkuv, et Körber on kasutanud sõna Zuname 'lisanimi', kuigi PR lahtri pealkiri, kuhu märkus on kirjutatud, juhendas märkima lahtrisse pn (Familien-Name). Tõenäoliselt on ta kasutanud sõna Zuname tähenduses 'liignimi; kõrvalnimi' ehk see, mis tuli talupoegadele kirjutada eesnime järele. Pn ehk Familienname oli tema ja ta isa jaoks talupoegadel juba ammu olemas ning seda kasutasid nad eesnime ees.

Teine nüanss tsiteeritud märkuse puhul on, et L. Körberi hinnangul talupojad valisid endale pn ise. See toimus küll juba 1820. a-il, sest HL26 fikseeris Kooskora peredele pn Koor. Hoolimata endale ise nime valimisest on hiljem mõnel puhul nende pn muudetud nimeks Kooskor(a) nii PR-s kui ka HL-s (vt ptk 6.2).

Lisaks terminile Zuname on pastor L. Körber kasutanud ka Gutsname 'mõisanimi' ja Beiname 'kõrvalnimi'. Beiname all mõtles Körber arvatavalt hüüdnime. Gutsname on tähistanud mõisas talukohale fikseeritud nime, mis ei läinud kokku aga kohapealse kasutusega, sest uue pere tulekuga oli koht saanud uue nime.

Nimedega tegelemisel on pastor L. Körber teinud PR42-s mitmeid märkmeid. Nt Mällo Hinriko l[e]sk Ello kohta on lisatud, et Hinrik on meetrikaraamatus Jani Merti Hinrik, PR-s Sonatari Hinrik (RA37:29, L 35). Mõtsa pere kohta on ta lisanud, et neid on $\operatorname{Im} A S V$ [=alte 
Seelenverzeichniss] auch Wirro genannt 'vanas hingekirjas (=PR-s) ka Virroks kutsutud' (RA37:11, L 9).

Kuigi osas mõisades olulist pn-de korrigeerimist ei toimunud, tehti mõne mõisa puhul seda massiliselt. Kõige rohkem on PR42-sse pn-sid juurde kirjutanud 1832-1864 ametis olnud köster Gustav Friedrich Hollmann, vähem pastor L. Körber (vahemikus 1842-1846), üksikud ka 1847-1877 pastoriametis olnud Gustav Oskar Oehrn. Kuna kogu 1855-1871 kasutusel olnud PR on algul kirja pandud köster Hollmanni käekirjaga, tegeleski tema 1855. a pn-de korrastamisega, märkides need ka eelmisse raamatusse (PR42).

Leidub juhtumeid, kus PR42-s on perele pn pandud, kuid hiljem on see ära jäetud. Nt Wirrolasse perele on PR42-s lisatud pn Wirro, kuid PR55-s on pn Wirrolasse. Samuti PR42-s on Sawa perele lisatud pn Sawason, kuid PR55-s on ikka Sawa.

PR42-s esineb lausa kolmekordseid nimeparandusi. Kiljako Kaarlele on kõigepealt kirjutatud pn Libbese, seejärel Jaanson ning viimaks Kilak, ülejärgmises PR-s (PR71) on ta nimeks Killak. Kui ühed Ahja mõisa Saava pered said PR42-s algul pn Sawason ning teised Matzon ja Sawas, siis veidi hiljem on Savasonid veel omakorda kolmeks jagatud: Sawason, Sawa, Sawik.

Vähemalt ühel puhul on nimemuutmine toimunud kroonupalati käsul. Rasina talupoja Joosep Juksaare puhul on PR42-sse pastor Oehrni käekirjaga lisatud nimi Freiberg ja märkus, et „kroonupalati käsuga 29.09.1850 selliseks ümber nimetatud“ (umbenannt) (RA39:15, L 20). Kusjuures tegu ei ole samade inimestega, kes HL26-s kandsid nime Freyberg, viimased kadusid Rasinalt 1845. a-ks.

Toimus ka parandusi, mille tagajärjel oli inimesel kolm eri pn. Tilga Paali Jakobi p Viilip sai Räpina PR (RA13:210, lk 514) ja HL järgi (RA21:16, L 17p) pn Paalmann, PR42 järgi aga Palitilk, millele on hiljem lisatud Hersow (RA39:69, L 126p). Nime Hersow kandis Viilip edaspidi pn-na, kuid Palitilk jäi talle PR-s n-ö teiseks eesnimeks surmani.

Nimede segadus PR42-st järgmisse (PR55) ümber kirjutamise puhul oli tavapärane. Kirikumõisa piirkonnas elavale Mällode sugukonnale fikseeris L. Körber arvatavalt 1842 pn-ks Mäll, köster Hollmann kasutas PR55-s aga pn-na nende lisanime ehk Mällo. Aasta varem (1854) oli pastor Oehrn PR42 alusel selle perekonna kohta väljastanud kirikutähe pn-ga Mäll (RA33:38). 
Meetrikaraamatutes on 1854. a-ni kasutatud veel „vanu“ nimesid. Näiteks 1854 sündis Johan Piir, kelle isa oli Piri Mert. 1859 sündis aga tema õde An Mäggi, kelle isa oli Mert Mäggi. Kusjuures Märdi vennale Kersnale on köster Hollmann kirjutanud samuti uueks nimeks Mägi, kuid pastor Oehrn on selle hiljem parandanud tagasi Piiriks.

1839 sündis meetrika järgi Kersna Hinrik Sulbi poeg Josep Sulbi, 1852 sündis tal meetrika järgi vend Taniel Sulbi, 1854 vend Peter Sulb, 1855 novembris vennatütar Sohwi Salop ja 1856 ka juba vend Kusta Salop. Pn Sallop on neile määratud juba HL26-s ning seda kandsid nad ka HL58-s. PR42-s on neile küll kohe algul lisatud pn Salop, kuid meetrikas on kasutatud lisanimest moodustatud pn Sulb $\sim$ Sulbi. Alles 1855, kui võeti kasutusele uus PR, hakati nii PR-s kui ka meetrikates nende kohta kasutama nime Salop.

Kirikuraamatute nimekasutuse kohta saab üldistavalt öelda, et 1854. a-ni kasutati meetrikaraamatutes valdavalt lisanimest moodustatud pn, mis ei kattunud sageli HL-s leiduva pn-ga. 1855 tegi köster Hollmann nimekorrastuse, võttes meetrika- ja personaalraamatutes (sh juba käibelt väljunud PR42-s) kasutusele paljud uued pn-d, mis omakorda ei kattunud HL omadega. PR42-sse kirjutati küll osa pn-sid kohe sisse ning need kattusid HL omadega, kuid meetrikates neid ei kasutatud, vaid pigem olid need teadmiseks.

\subsection{Hingeloendite ja personaalraamatute võrdlus}

Siinse analüüsi jaoks olid kaks peamist allikat Võnnu kihelkonna mõisade 1826. a HL-d (HL26) ning Võnnu luteri koguduse 1842-1855 peetud PR (PR42) ning viimases toodud isikuandmeid on vajadusel võrreldud 1806-1839 (selles pn-sid ei esine) ning 1855-1871 peetud PR-ga. Nimede kasutust kirikuraamatutes on kirjeldatud peatükis 6.1.

HL-s hakkas pärast pärisorjuse kaotamist tekkima fiktiivne rahvastik, st loenditesse märgiti talude alla ka talupojad, kes tegelikult elasid ja töötasid juba linnades, vabrikutes jm, kuid olid jätkuvalt oma kodukogukonnas hingekirjas. Vaadeldaval perioodil oli liikumine aga veel väike. Juhan Kahki järgi lahkus Eestimaa eramõisades aastail 18351844 oma kodukogukonnast ümberarvestuse järgi 3728 talupoega (Kahk 1969: 138). Kuna kubermangus oli tollal veidi üle 200000 talupoja, moodustas lahkunute arv vaid paar protsenti. Pärnu- ja Viljandimaal 
lahkus oma kodukogukonnast 1827-1841 ligikaudu 5\% talupoegadest (arvutuse alus: Must 2000: 149, Tannberg 2010: 152). Tõenäoliselt lahkus aastani 1842 ka Võnnu kihelkonnas oma kogukonnast vaid väike osa elanikke ning PR42 andmed on üsna võrreldavad HL26 andmetega.

Et analüüsi ühe allikana kasutati luteri kirikuraamatuid, ei kajasta see õigeusklikke. Samas polnud ka suur osa peipsivenelastest kirjas mitte kohalike mõisade HL-s, vaid linnades (Tartus, Viljandis, Võrus, Lätis), sageli isegi teises kubermangus (nt Paides, Rakveres). Sel põhjusel jääb õigeusklik elanikkond siin vaatluse alt välja, kuna valdav osa neist ei kajastu kummaski analüüsitud allikaliigis. Uuritavasse perioodi jääb küll eesti talupoegade õigeusku minek, kuid Võnnu kihelkonnas oli konversioon üks madalamaid kogu Liivimaal: kogu kihelkonna keskmine oli Hans Kruusi (1930: 358) järgi 2,9\%, mida tõstavad vaid kahe mõisa (Kiidjärve 15,6 ja Rasina 11,7) kõrgem protsent, teistes mõisades on see alla kihelkonna keskmise. Madalat osakaalu selgitab Kruusi arvates rahva hea vahekord abipastor Louis Körberiga.

Analüüsisime pn-de kujunemist ja arengut neljas mõisas: 1) Ahja kui kihelkonna suurim mõis (ca 26\% kihelkonna talupoegadest), 2) Poka kui üks mõis suuremast mõisakobarast (koos Mäksa ja Kastrega), mis kokku hõlmas samuti ca 26\% kihelkonna talupoegadest ja kus nimepaneku korraldus oli suure tõenäosusega ühine (mõisakobara all mõistetakse mitmest juriidiliselt iseseisvast mõisast koosnevat kogumit, mida uuritaval ajal majandati ühiselt), 3) Rasina kui tõenäoliselt suurima Räpina (ja Võrumaa) mõjutustega mõis ( $c a$ 8\% kihelkonna talupoegadest) ning 4) kirikumõis ( $\mathrm{ca} 1,4 \%)$ kui koht, kus pn-de panekuga tegeles pastor. Kokku annab see võimaluse teha järeldusi üle $60 \%$ Võnnu kihelkonna talupoegade pn-de kohta kahes allikaliigis.

PR42 andmetest on analüüsitud neid elanikke, kelle puhul on viide andmete leidumisele eelmises PR-s samas mõisas ehk tegu pole hiljuti sisserännanutega ning uuritavad elasid seal nähtavasti ka 1826. a. Kahtluse korral, millist pn sooviti fikseerida, kontrollisime nimekuju PR55-st. Analüüsil on välja jäetud üksikud inimesed või perekonnad, kelle kõik liikmed surid, lahkusid või abiellusid PR42 pidamise ajal ja kelle puhul on raske kontrollida, kas neile pn korrastamise ajal mingi pn kinnistati ning mis nime nad kandsid HL-s. Neist on sisse võetud nimed, mis HL-s esinevad, ning välja jäetud need, mis ei esine. See võib võrdlusel olla kahandanud pn-de lahknevust PR ja HL vahel, samas mõni teine tegur on seda suurendanud. Viimast võib tulla ette juhtudel, kui 
PR-s esineb perekonnanimi vallaslastel või naise lastel eelmisest abielust ning see ei kajastu HL26-s, küll aga esineb HL34-s. Nt Rasinal ei esine HL26-s Raudsepa Katre ega ta 1823 sündinud vallaspoeg Peeter, HL34-s aga juba esineb (Katre pn-ga Viksi, Peeter aga pn-ga Tamm), PR42-s on poja nimi samuti Tamm. Järelikult polnud tegu poja näol eri nimedega, vaid andmete puudumisega HL-s, ema puhul pn kirikuraamatutest ei selgu. Isikuti andmeid vastavusse viia oleks äärmiselt töömahukas. Teadmatusse jäävate kattuvuste ja mittekattuvuste hulk võib olla enamvähem tasakaalus ning see analüüsi tulemust suures plaanis ei mõjuta.

\subsubsection{Kirikumõis}

Kirikumõisas vastavad HL ja kirikuraamatute pn-d teineteisele hästi. Palju on olnud talupoegade liikumist, seetõttu ei leia me PR42 kirikumõisa osast mitmeid nimesid, mis on kirjas HL26-s (Abbenick, Päär, Poska, Saerre), kuid leiame nende või nende sugulaste andmed meetrikaraamatutest või PR42-st teiste mõisade alt samade pn-dega. Vastavust selgitab asjaolu, et nii kirikuraamatuid kui ka kirikumõisa HL pidas pastor. HL26 järgi pandi 14 pn, PR42 järgi 11 (arvestades Kilk ja Kilgi eraldi nimedeks). Viimastest vaid üks (Lokkenberg) ei esine HL-s (seal on see Mell). HL nimedest, mida PR-s ei leidu, on enamiku näol tegu kas varsti kadunud nimedega või nendega, mis on mujalt sisse rännanud ning pole PR-s kirjas kirikumõisa all.

Kirikumõisa HL26 puhul on oluline märkida, et sellest on säilinud ümberkirjutus, mitte pastor Körberi koostatud algeksemplar. Seetõttu pole teada, kas nimesid on kihelkonnakohtus või kroonupalati revisjonikomisjonis muudetud. Kui võrrelda HL26 ja HL34 (mis on Körberi enda käega kirjutatud), siis näeme seal omavahel mitmeid erinevusi: Laur $>$ Laar, Laar $>$ Laur, Lohk $>$ Lohha, Moser $>$ Moses jt. Kuna talunimi oli Moses, siis tõenäoliselt oli algselt mõeldud ka pn Moses, kuid kihelkonnakohtus või kroonupalatis parandati see Moseriks.

\subsubsection{Poka}

Poka mõisa HL26 järgi pandi seal talupoegadele 63 pn. Ees olevas registris puudub kuus (11\%) nime, sest need pandi ainult naisterahvastele (Ehhijerw, Kihhijo jt). Nimede kirjapilt varieerub (nt Patzi Paatzi $\sim$ Paazi $\sim$ Pazi), kuid aluskäänetega pole varieeritud. 
HL26-s leiduvast 63 nimest ei ole PR42-s lausa 35 (56\%). Välja arvates 1842. a-ni lahkunud, üksikud naisterahvad, kelle andmeid on keerukas teisest allikaliigist üles leida ning kelle nimede kattuvus pole seetõttu välistatud, samuti Mäksa mõisa all leiduvad nimed, jääb mittekattuvateks vaid kaks, kelle nimi juba HL34-s parandati (nt HL26 Tamme, aga HL34 Michkli) ning kaks nime (Menni ja Mutso), mille kandjate puhul on PR-s kasutatud kolme eri pn. Mäksa mõisa andmeid tuleb arvesse võtta seetõttu, et Poka ja Mäksa olid ühe mõisakobara osad ning paljud PR-s Mäksa all kirjas olevate perede liikmed olid kirjas Poka HL-s.

Võrreldes PR42 nimesid HL nimedega, on olukord teine. PR42 Poka osas leidub 35 pn - vaid pool HL-s leiduvast kogusest. Mitmed Poka HL pn-d leiame küll PR Mäksa osast, kuid on ka palju pn-sid, mille kandjatel on HL-s teine pn: PR Anderson / HL Prakly, Hannusse/ Kibal, Hinrikson/Prakly jt. Välja paistab tendents, et HL-s laialt levinud (lisanimega sama) pn kandjad on PR-s jaotatud sugulussuhete kaudu ning neile on pandud teised nimed. 35 nimest ei leidu HL-s 10 ehk $29 \%$. HL58 originaalnimeregistri järgi on neist nimedest neli jõudnud ka HL-sse. Parandatud on teisigi nimesid, seda küll vaid mõne nimekandja osas. Nii leiame, et mõnest varasemast Kibalist on saanud Miitra (Kibbal jetzt Mitra), kuigi nimed Kibal ja Miitra esinesid mõlemad varemgi ka teistel inimestel nii HL-s kui ka PR-s.

Poka mõisa põliste elanike pn-de hulk kahe allikaliigi peale kokku on 73, millest kuus (8\%) leidub ainult PR-s. PR ja HL nimede suurt lahknevust mõjutab asjaolu, et paljud inimesed olid PR-s kirjas Mäksa mõisa all, HL-s aga Poka all ning nähtavasti ka vastupidi.

\subsubsection{Rasina}

Rasina mõisa HL26 puhul vastavad ees registris ning sisus olevad pn-d teineteisele peaaegu täpselt, kui välja arvata mõned ortograafilised kõikumised (nt Pock $\sim$ Pok, Johanson Johansohn). Nominatiivsete ja genitiivsete nimekujudega varieerumisi ei leidu. Registrist on välja jäänud vaid üks, ainult naisterahvale pandud pn Munga, mis on eraldi numbri all ning järelikult pole seda mõistetud nime Muga või Mung variatsioonina, mis oleks Ahja puhul tavaline (vt ptk 6.2.4). Kokku on Rasinal pandud 67 pn. 
PR42-s leidub Rasina mõisa osas kohalikel talupoegadel 57 pn. Neist viit ei leidu HL26-s üldse (Hanni, Hanniotti, Treu jt) ning neli on lisanimed, mille sarnaseid pn-sid HL-s esineb (Kaddaja, Zirn, Zirna, Tiriko), kuid kuna nende kandjad eri allikates ei kattu, tuleb need lugeda mittekattuvateks. Nii on PR42 nime Zirn kandjad HL26-s Zern. PR42 nime Zirna kandjad aga HL26-s Zirn. Üheksast mittekattuvast on HL58-sse jõudnud kolm, kuus jäid kirikuraamatute omadega ühtlustamata.

Kui vaadata nimede ühtlustamist HL58-s lähemalt, selgub, et seda tehti tegelikult vaid osaliselt ning eesmärk polnud viia kõik kirikuraamatute ja HL nimed kokku. Näiteks PR-s Hanniotti ja HL-s Otto nime kandva sugukonna liikmetest on ka 1858 HL-s üks haru jätkuvalt Otto nimega, teine aga (Otto) Hanniotti nimega.

Uurides kattumist teistpidi (HL > PR suunal), siis HL26-s leiduvast 67 nimest ei leia me PR42-st vasteid 17 nimele (25\%). Nendest kolm olid õigeusklikud ning ei saagi PR-s kajastuda. 11 nime puhul nende kandjad surid või lahkusid või pole jälgitavad mõlemas allikas. Kuue nime puhul (9\%) nimed selgelt ei kattunud: HL26 nime Jaans kandjad on kirikuraamatutes Hanno, nime Mung kandjad Muga, nime Muug kandjad Muga ja Kersna jne.

Rasinal on kokku pn-varamu olnud 76 nime (67 HL nime ning lisaks üheksa PR-s nendega mittekattuvat nime). Neid on üldiselt püütud omavahel vastavusse viia. Kui esialgu ei kattunud umbes $16 \%$ nimedest, siis 1858. a-ks kahanes nende osa 10 protsendini, kuid see näitab vaid kattuvate pn-de, mitte aga nende nimede kandjate hulka - viimaseid omavahel alati vastavusse ei viidud.

Rööpsete pn-de lai valik tuleb kenasti välja Võnnu-Kärsa õigeusu koguduse materjalidest, kuna nendes on kohati kasutatud nii luteri kirikuraamatute kui ka hingekirjutuse dokumentide andmeid. 18881891 peetud Rasina vallas elavate koguduseliikmete nimekirjast leiame pn-d Muuga (Abenik), Muuga (Sawi), Muuga (Kärsna), Otto (Muuga), Tiirik (Muuga), Pokk (Munga) jt (RA23:3-4, L 1-1p), kusjuures kõik sellised nimepaarid eeltoodud analüüsiga välja ei tulnud, järelikult oli lahknevate nimede hulk suuremgi.

Juhtumianalüüsina käsitleme Rasinalt ühe perekonna andmeid, kellest osa said HL ja PR järgi sama pn, osa aga erineva pn. Näide iseloomustab, mida rööpsete nimede kasutus kaasa tõi, kuidas see kajastus eri liiki dokumentides ning kuidas see on kandunud tänapäeva välja. 
Muuga või Kersna? Rasina mõisast uurisime suurima, Muugade sugukonna ühte haru. Muuga Jaagu Jaani ehk Muuga Kersna Jaani (1753-1836) pere sai HL26 järgi pn Kerstna, PR42 järgi Kersna. Jaani väimees, Muuga Tiiriku Peebu poeg Aadam ( $c a$ 1775-1827) sai nii HL26 kui ka PR42 järgi pn Muuga. Aadam ei saanud Muuga lisanime oma äia, vaid isa kaudu. Jaani venna Johani pojad kandsid HL26 järgi nime Muug (või Mung³), PR42 järgi aga Kersna. HL34-s kannavad Johani kaks poega juba pn Muga, kolmas on Mung ning tema tütar, kui ta läks elama oma lelle perekonda, kannab HL58-s pn Muga.

Perekonnad, kes olid PR-s Kersnad, HL-s aga lõpuks Muugad, kandsid Muuga nime ka vallaliikmete nimekirjades (RA44:9, L 9p-10). Erinevalt eeltoodud näitest Juksaar-Freibergi kohta pole nendele 1875-1890 nimekirja ega ka mitmetesse hilisematesse kirikuraamatu rööpnime märgitud. Seda tehti alles hiljem: 1911-1915 nimekirjas on Муга, 1916 aga Муга (Керсна) (RA46:3, L 1p, RA45:90, L 91p).

Võnnu kirikuraamatutes kandsid uuritavad pn Kersna, kuid mujale minnes kasutati mõnikord ka kirikuraamatutes „passinime“. Tallinna Pühavaimu koguduses on Joosep Jaani p Kersna kohta lisatud märkus „passi järgi Muga, nii ka tema vend“ (TLA3:85, L 79p). Joosepile koos abikaasa Juuliga kinnistati 1930. a-il perekonnaregistrisse andmeid kandes pn-ks Muuga (TLA5, L 537-538). Huvitav on, et Joosepi sünnikandes on tema nimeks märgitud Joosep Muuga, kuid isanimeks Muuga Jaan Kersna (RA42:449). Kuna perekonnaregistrisse pidi isiku nime kandma sünnikandes esineval kujul (Teder 1939: 20), siis on Muuga nime fikseerimine õige, kuigi eksitus on olnud just sünnikandesse Muuga pn kirjutamine. Joosepi perekonnaregistri alusdokumendil, Võnnu koguduse pastori August Eini 1936 tehtud väljavõttele PR-st on ta kirjutanud Joosepi nimeks Kersna, lisades, et Joosep Kersna isa oli greeka õiget usku ja kutsuti Jaan Kersna, luteri usus on aga pg. Joosep ristitud Muuga perek-nime all. /.../ Nagu vanemad raamatud näitavad on Jaan läinud greeka õiget usku ja seal Kersna p.nime saanud, kuna tema isa lut. usku oli ja Munga Peep - Jaani poeg on seetõttu kui

HL26-s on kasutatud mõlemat nimekuju, kuid osa kirjapanekute (nagu just siin mainitud pere) puhul pole käekirjast selge, kumba neist on mõeldud. Ees registris on neid küll eristatud, kuid kuna register koostati hiljem ning mitte enam mõisavalitsuse poolt, vaid kroonupalatis, siis ei ole see usaldusväärne. HL34 koostaja on nähtavasti oma silma järgi kirjutanud osa neist oma selgema käekirjaga Muugiks, osa Mungiks. 
luterlane jälle meetrikas Joosep Munga'na sisse kantud (TLA8, dokument lk 537 juurde). Nimevahetuse põhjendamine usuvahetusega on muidugi alusetu ning Joosepi sünnikandesse kirjutati Muuga pn arvatavasti kogemata. Joosepi pojale Johannes-Albert Kersnale kinnitati 1935. a ametlikuks nimeks tema sünnikande nimi Kersna (TLA4, L 60, TLA2:370, L 391, RA31:270, L 262).

Joosepi lellepoja Joosep Aadama p Kersna (1868-1921, vt ka allpool) lesele Marile poeg Eduardiga kinnistas Rasina valla perekonnaseisuametnik pn-ks Kersna (RA59, lk 173-174). Huvitav on seejuures, et Rasina vallavalitsus kasutas oma tegevusaja lõpuni (1939) Mari kohta Muuga nime (RA53:64, L 71p, RA52:113, L 164p, RA54:52, L 34p), nagu ta ka ise oma allkirjaks kirjutas (RA56:335), kuigi perekonnaregistris oli seesama vallavalitsus tema ametlikuks pn-ks fikseerinud Kersna.

Joosepi vennapojale Viidale koos naise ja lastega kinnistas Ahja valla perekonnaseisuametnik perekirjas nimeks aga Muuga-Kärsna (RA60, 1k 212). Põhjus on selles, et kui Viida läks 1903 Võnnu kogudusest Põlva kogudusse, kirjutati sealsesse PR-sse sulgudesse pn Kersna kohale (Muuga) (RA32:13, lk 436) ning järgmisse raamatusse kirjutati nimi juba Kersna (Muuga) (ELK.18.0.11:239, L 218p-219). Hauatähisel on ta nimi Viido Muuga, nagu ka tema teistel perekonnaliikmetel (Haudi), kuigi tema abikaasa Julie surmaaktil (1964) on perekonnanimi Kersna (RA57), tema matmississekandes Põlva koguduse surmameetrikas on Kersna-Muuga (ELK.18.0.8:181). Nende minia Luise surmaaktil (1977) on pn Muuga (RA58). Tõenäoliselt jäeti topeltnime üks pool Nõukogude ajal ametlikus asjaajamises välja, kuid on juhus, kumb nimi alles jäeti.

Viido vennale, kelle nimi oli Jaan Kersna (Muuga), otsustas siseminister 1939. a määrata uueks pn-ks Muuga (Riigi Teataja Lisa 1939, 59, 1948). Jaan Muuga sünnikandes oli algselt vaid pn Kersna (RA41:31, L 31) ning selle alusel oleks ta ametlikuks nimeks pidanud saama ka perekonnaregistris Kersna. Jaan oli seni kasutanud topeltnime Kersna-Muuga, seda ka allkirja andes, kuigi kohati oli tema allkirjaks ka vaid Kersna (RA51:3, 5-6, L 1p, 2p-3). Edaspidi oli ta ametlikuks pn-ks Muuga.

Ametlike pn-de kõrval on alati olnud ka mitteametlikud. Kui E. P. Körberi eesmärk tõenäoliselt oligi säilitada rahvasuus kasutusel olnud lisanimed ametlike pn-dena, siis alates 1840. a-ist kirikuraamatud 


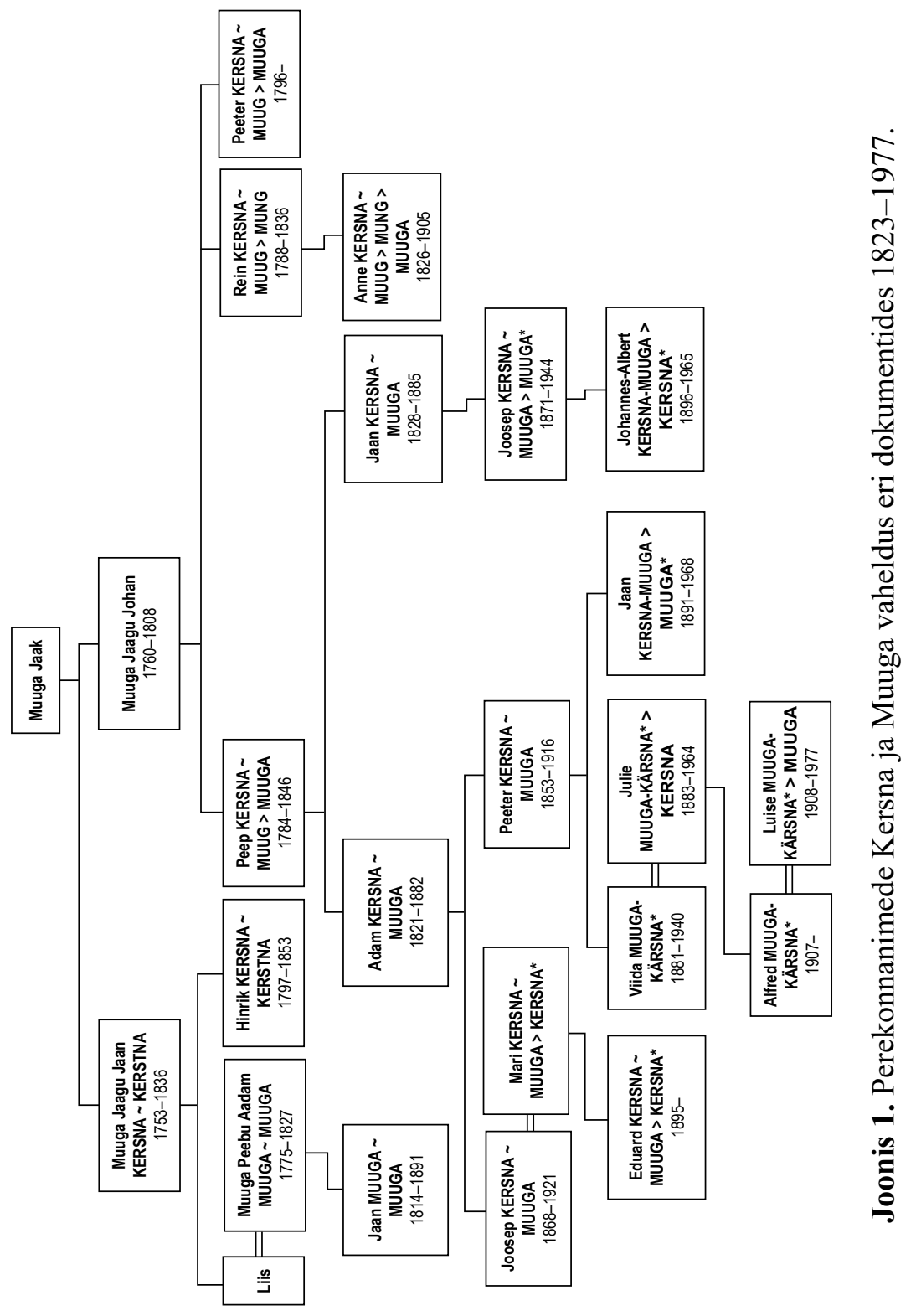


neid enam ei kajastanud. Huvitava näitena on meil teada murdetekst 1951. a-st, kui Rasina külasepp Joosep Aadama p Muuga (1878-?) mainib teist külaseppa: [porgandi joozep, kah munga nimi] (Keem 1970: 308). Porgandi ehk Pori (EKI KN: Võn EKI2) talus elanud mees kandis kirikuraamatute järgi nime Joosep Aadama p Kersna (1868-1921, vt eespool) ning Muuga oli ta pn HL-s ja valladokumentides. Järelikult oli XX sajandi keskelgi kunagiste lisanimede, mitte aga ametlike pn-de kasutamine jätkuvalt primaarne.

Joonisel 2 on näidatud Muuga-Kersna sugukonna liikmete pn-de muutused. Läbiva suurtähega on esikohal kirikuraamatute, pärast tildet HL ja vallaliikmete nimekirjade nimekujud. Ilma tildeta on nende isikute pn-d, kelle kohta on teada nime ametlik fikseerimine 1930. a-il (märgitud tärniga), osal juhtudel järgneb veel hilisem nimekuju.

\subsubsection{Ahja}

Ahja mõisa HL26-s on numeratsiooni järgi 140 pn, üks nimi (Torro) on antud üksikule naisele, seetõttu nime HL ees olevas registris ei leidu. Sisu järgi koostatud nimeregistri abil selgusid veel neli pn, mille said samuti ainult üksikuid naised ning mis seetõttu registris ei kajastu. Neil puudub ka pn number. Neist kaks olid sisserännanud, kuid ühe puhul ei pandud sama nime tema algkodus ning ta võis nime saada juba Ahjal. Kokku fikseeriti Ahjal 144 pn (registris ei kajastu 3,4\% nimedest).

HL26 ees oleva registri ja sisu võrdlemisel leiame mitmeid erinevusi. Sama numbri all on sisus Palg ja Pulga, samuti Sack ja Sae. Registris on kummastki paarist vaid üks nimi, need on loetud üheks nimeks ning nähtavasti põhjendatult. Pung on registris kahe eri numbriga, mis sisus on nimedena Pang (nr 129) ja Pung Punng Punnig (nr 49), st loetud kaheks eri nimeks. Paraku on nime Pang kolmest esinemisest kahe puhul kirjutatud nimeks algul Pung, kuigi number on 129, hiljem (kroonupalatis?) on $u$-täht parandatud $a$-ks. Korduvalt on meespere saanud (parandatud) pn Mikkelsaar, sama pere naised (naised ja mehed on HL-s kirjas vastastikustel lehekülgedel) aga Mikkelson. Teisal on mehed saanud pn Saarwe, naised aga Saarwas. Samas Saarwa ja Saarwe esinevad vaheldumisi ühe numbri all (on loetud üheks nimeks), Saarwas aga teise numbri all. Osa naiste puhul on järelikult kirjas mitte nende meespere, vaid mõne teise pere meeste perekonnanimi, mis on hiljem jäetud parandamata. 
Nimede varieerumise puhul ei saa ilma lähemalt kontrollimata teha järeldusi, kas nominatiivse ja genitiivse vormi puhul on mõeldud sama nime või eri nimesid. Kurg, Kurk ja Kurrik on kõik ühe numbri all (kuigi olemas olid nii Kure kui ka Kurika talud). Registris on neist vaid Kurrick. Saag ja Sae on eri, Nagel ja Naggla sama numbri all. Sarnaselt kirikuraamatutele on nominatiivne ja genitiivne kuju loetud reeglina samaks nimeks, kuid sellest on palju erandeid.

Jättes kõrvale õigeusklikud ning 1826. a-ks sisserännanud (kuna viimased võivad olla kirikuraamatutes veel oma vana elukoha all), on PR42-s puudu 23 pn, mis HL26-s esinevad (varieeruvad nimed on loetud üheks, nt Lett ja Letti). Nende hulgas on üksikuid naisterahvaid, 1842. a-ks lahkunuid ja surnuid. Rööpseid pn-sid võib PR42-ga võrreldes kokku olla järelikult kümmekond ehk umbes 7\%.

PR42-s leidub Ahja mõisas 265 eri pn. Erinevaks on siin loetud nominatiivsed ja genitiivsed nimed (Mollok ja Molloka; Pedokes ja Pedokesse), samaks aga väikese ortograafilise erinevusega nimed (Matson $\sim$ Matzon). Nominatiivsete ja genitiivsete nimede paare on 17 ning kuna paljud neist hiljem sulandusid, osa aga mitte, võiks nimede üldarvuks lugeda umbes 255. Neist HL26-s ei esine 135 nime (53\%) ehk peaaegu sama kogus, kui on HL nimesid üldse kokku (144). HL58-sse on jõudnud sarnaselt Rasina ja Poka mõisaga umbes $2 / 3$ juhtudest PR42-s juurde tekkinud pn-dest, kuid mitte kõikide nimekandjate puhul ning HL58-sse tekkis juurde veel uusi nimesid.

Ekstreemne näide ühe pn esialgsest ülisuurest levikust ning hilisemast massmuutumisest on Ahja mõisas antud pn Piir (Pier $\sim$ Pieri). Selle said HL26 järgi 143 talupoega (5,7\% Ahja mõisa talupoegadest, HL50 järgi juba 264 kandjat ehk 8,4\%), kes tõenäoliselt kõik kandsid rahvasuus Piiri (< Spiridon) lisanime. Kui üksikute eri taludes elanud inimeste vahel ka leidub sugulussuhteid, on siiski tegu kokku mitmekümne eri sugukonnaga.

PR42-s on Piiri peredele lisatud kohe või hiljem 29 eri pn (Müür, Mertens, Kripson, Mehhine jt). Nimed on lisatud kolmes järgus: pastor L. Körberi poolt kohe 1842 kirja pandud (5), köster Hollmanni poolt hiljem lisatud (23) ja pastor Oehrni poolt lisatud pn-d (1). Osa peresid jäi kandma pn Piir või Piiri. Juurde kirjutatud 29 nimest esinevad HL26-s sama või sarnasena üheksa. Andmeid isikuti võrreldes selgus, et nendest valdav enamik ei ole paraku antud samadele inimestele, kes said need nimed hiljem PR järgi. Nt Kersten küll esineb HL26-s, kuid 
tegu on juba 1818 nekrutiks võetud mehega ning PR42 järgi sai selle nime hoopis teine perekond.

1855. a-ks PR42-s kasutusele võetud 29 nimest 21 võeti HL58-sse üle (kirjutades need kujul Märtinson /Piir/), kuid mitte isikute täpsusega. Kui näiteks Grünbergi nime kandjad kattuvad nüüd PR42-s ja HL58-s täpselt, siis PR42-s nime Kripson saanud sugukonnast on üks haru ka HL58-s Kripson, teine aga Krips, millist nime ei esinenud varem ei HL-s ega esine kunagi PR-s. Kripsi nimi ei kestnud kaua. Kui 1873 koostatud vallaliikmete nimekirjas on nimi olnud veel Krips, on sinna hiljem lõppu lisatud -on (RA47:66, L 54p-55) ning 1888 alustatud nimekirjas on juba kohe kirja pandud kirikuraamatutega kattuv pn Kripson (RA48:99, L 90p-91).

Mõnel puhul on kasutusele võetud aga veel kolmas või neljaski nimi. Nii oli üks perekond HL26-s Pierson, HL34-s Pier, PR42-s Kersten ja HL58-s Kersnason, teine HL26-s, 34-s ja 50-s Pier, PR42-s Kramann, HL58-s Tönn jne. HL58-s ühtlustati 69\% puhul nimi PR42 omaga, 6\% puhul toodi kasutusse uus nimi, ülejäänud kattusid juba varem või ei ole kontrollitavad.

Ahja mõisas toimus 1850. a-il suur nimede muutmine, seejärel ühtlustamine PR ja HL nimede vahel, kuid ei ühtlustatud kõiki nimesid, üksikud jäid ainult kirikuraamatutesse, üksikuid tekkisid ainult HL-sse seniste asemele juurde, kandudes sealt edasi ka vallaliikmete nimekirjadesse, näiteks Кярстенъ/Керснасонъ (RA49:366, L 358p). Juhtus ka tagurpidi parandamist: pere, kes on HL järgi Piir ning PR42 järgi Kure, on PR55-s parandatud tagasi Piiriks, kuid HL58-s omakorda Kureks.

\section{3. Üldistused}

Pn-de kasutuse Võnnu kihelkonna eri allikates võib kokku võtta järgmiselt. HL26 fikseeris kõikidele talupoegadele perekonnanime. Eri mõisades oli nimede ühtlus läbi terve hingeloendi väga erineva tasemega. Mõnes mõisas varieerus üks ja sama nimi vaid ortograafiliselt, teisel vaheldus selle aluskääne ning samas perekonnas (sh meestel ja naistel) esines sarnaseid eri nimesid, mistõttu on keerukas järeldada, kas mõeldi ühte ja sama või mitut eri nime. Üksikuid muudatusi pn-des (ühtlustusi kirikuraamatutega või ka muid muutusi) viidi sisse juba HL34-s. HL26 ees olevatest pn-de registritest vastas sisus olevatele nimekujudele hästi Rasina, enam-vähem kirikumõisa ja Poka 
ning väga halvasti Ahja mõisa HL. HL sisus esinevatest nimedest pole kirikumõisas puudu ühtegi, Rasinal vaid üks nimi, Ahjal on puudu 3,4\% ning Pokal $11 \%$ pn-dest. Sisu järgi loodud nimeregistrid võimaldaksid täiendada Aadu Musta koostatud onomastika andmebaasi (Onomastika). Sama andmebaasi võimalik täiendamine kirikuraamatutes tekkinud rööpnimedega oleks aga palju keerukam ülesanne.

1834. a-st hakkas (küll ebajärjekindlalt) pastor E. Körber senist eesnime ees asuvat genitiivset lisanime kasutama eesnime järel täpselt sama, genitiivse või nominatiivse vormiga pn-na. Vaid harva kasutas ta talupoegadel HL-s esinevat pn, kui see oli lisanimest erinev. 1842 koostas tema poeg, abipastor L. Körber PR, kuhu pani kirja vähemalt osa HL-s esinevaid lisanimest erinevaid pn-sid, kuid meetrikates neid tavaliselt ei kasutatud. 1847 ametisse asunud uus pastor Oehrn jätkas esialgu sama süsteemi. 1855 koostas köster Hollmann uue PR, võttes selle käigus ette ka pn-de korrastamise. Ta võttis kasutusele palju uusi pn-sid, jagades senised ühise lisanimega sugukonnad väiksematesse perekondadesse. HL-s olnud kirikuraamatutest lahknevaid pn-sid ning Hollmanni loodud uusi pn-sid hakati kasutama 1855. a-st ka meetrikates. Pastor Oehrn tegi Hollmanni fikseeritud nimedesse ka parandusi. Ebajärjekindlalt vaheldusid nime genitiivne ja nominatiivne vorm kõikides allikates.

Võnnu kihelkonnas on rööpnimedel olnud seega mitu eri perioodi: aastad 1822-1833, kui HL-s olid kasutusel spetsiaalselt pandud pn-d, kirikuraamatutes kasutati vaid lisanimesid; 1834-1854, mil kirikuraamatutes olid kasutusel valdavalt lisanimedest moodustatud pn-d, mis tihti ei kattunud HL nimedega; 1855 võeti PR-s kasutusele paljud uued nimed, mida varem ei esinenud kusagil; alates 1858 , mil HL-sse võeti osad PR uutest nimedest, kuid mitte kõik, ning säilinud rööpnimed jäid kehtima enamasti 1930. aastateni.

Kõrvutades kahes eri allikaliigis esinevaid kohalike perekondade pn-sid, selgus, et HL26-s leiduvatest pn-dest leidub PR42-s 91-100\%. Vastupidi ehk PR42 nimedest leidub HL26-s aga 47-91\%. Järelikult enamikus mõisades tekkis PR-sse juurde palju uusi nimesid, Ahja mõisas lausa sama palju, kui neid enne oli olnud. Enamasti on viimaste näol tegu nimedega, mis loodi 1855 köster Hollmanni poolt selleks, et samanimelisi mittesugulasi või väga kaugelt sugulasi omavahel eristada. Kirikumõisas vastavad HL ja PR nimed hästi, kuna mõlemaid koostasid kirikuõpetajad. Vaid üks nimi ei kattu HL ja PR vahel. 
Tabel 1. Võnnu kihelkonna nelja mõisa hingeloendite ja personaalraamatute perekonnanimede võrdlus

\begin{tabular}{llcccc}
\hline Mõis & $\begin{array}{l}\text { HL26 } \\
\text { nimede } \\
\text { varieeruvus }\end{array}$ & $\begin{array}{c}\text { HL } \\
\text { registris } \\
\text { puuduvaid } \\
\text { pn }\end{array}$ & $\begin{array}{c}\text { HL26 } \\
\text { > PR42 } \\
\text { pn-de } \\
\text { vastavus }\end{array}$ & $\begin{array}{c}\text { PR42 } \\
\text { HL26 } \\
\text { pn-de } \\
\text { vastavus }\end{array}$ & $\begin{array}{c}\text { PR42 } \\
\text { nimedest } \\
\text { võetud üle } \\
\text { HL58-sse }\end{array}$ \\
\hline Ahja & suur & $3,4 \%$ & $93 \%$ & $47 \%$ & $67 \%$ \\
kirikumõis & keskmine & $0 \%$ & $100 \%$ & $91 \%$ & $0 \%$ \\
Poka & väike & $11 \%$ & $94 \%$ & $71 \%$ & $40 \%$ \\
Rasina & väike & $1,5 \%$ & $91 \%$ & $84 \%$ & $33 \%$ \\
\hline
\end{tabular}

Sageli ühe pn (kõik) kandjad ühes allikas ei ole samad kui sama pn kandjad teises allikas. Seega võrreldes isiku tasemel perekonnanime kahes eri allikaliigis on lahknevused veelgi suuremad.

1/3 kuni 2/3 PR42 kasutusele võetud nimedest võeti üle HL58-sse (kirikumõisa üks nimi pole statistiliselt esinduslik). HL58-s loodi juurde veel mõningaid uusi pn-sid.

1874. a-st HL asemele tulnud vallaliikmete nimekirjad kannavad algul edasi HL nimesid, hiljem on neis mõlemad, nii HL kui ka PR nimed, enamasti esimene esikohal, teine sulgudes. Rasina vallas hakati nimede lahknevust märkima juba esimeste vallaliikmete nimekirjade puhul, kuigi pigem on tegu lihtsalt märkustega, hiljem on mõnikord esitatud topeltnimedena. Nt Juksaarte puhul on 1875-1890 nimekirja lisatud, et Freiberg kirikuraamatus kõik familie nimetud (RA44:13, L 13p), ning 1911-1915 nimekirjas on nimi Юксаръ-Фрейбергъ (RA46:11, L 9p). Vallavalitsuste iseseisvusaegsed elanike nimekirjad jätkasid samu, HL-st pärit nimede kasutamist isegi pärast seda, kui vallavalitsuse perekonnaseisuametnik oli perekonnaregistrisse kirikuraamatute alusel fikseerinud teise nime (vt ptk 6.2.3 Kersna-Muuga juhtumianalüüsist).

\section{Rööpnimed Roosna-Alliku mõisas}

Järvamaal Järva-Jaani (JJn) halduskihelkonnas, kuid Järva-Madise (JMd) ja JJn kirikukihelkonnas paiknevas Roosna-Alliku mõisas esineb palju rööpseid pn-sid. JMd kirikukihelkonnas asusid Roosna-Alliku mõisa Kihme, Härjapea ja Oeti küla ning JJn kihelkonnas Kaaruka küla ning osa Valasti külast. Mõlemas osas olid ka mõned hajatalud, mõisa 
osad olid enam-vähem võrdse suurusega: HL35 (RA15) järgi oli JJn osas 61, JMd osas 53 majapidamist.

HL35 sisaldab nimede numeratsiooni järgi mõisarahvale antud kuus ning külarahvale antud 187 pn (kokku 193). Samas on osa nimesid nähtavasti juba luues mõeldud ühe ja samana, kuid neil on väike ortograafiline erinevus ning nad on esitatud eri numbrite all. Nt nimi Moamees ja Moimees on esitatud eri numbrite all, kuid HL50-s (RA17) on mõlemad kujul Moamees. Korjokse ja Korjoksep on HL35-s eri numbrite all (kusjuures viimasele on $p$ alles hiljem lõppu lisatud), kuid HL50-s on mõlemad Korjokse. Tegelik eri nimede arv on järelikult mõnevõrra väiksem, alla 190.

HL35 järgi said paljud vendade paarid (või üks vend teistest eraldi) eri pn (Odrekse ja Puddini, Hawiko ja Toppa jt), kusjuures valdavalt elasid vennad HL järgi samas talus. Kirikuraamatute järgi leiame, et vähemalt osa neist elas tegelikult eraldi, mõned isegi eri kihelkonnas. Liivimaale sarnast sugulussuhete järgimist pn-de panekul järelikult siin ei kohta ning selle põhjus võib olla pastori väiksem või olematu roll algsel nimepanekul. Vähemalt ühel puhul on lausa vastupidine nähe: kui HL järgi said ühed vennad sama pn Sursim, siis PR järgi said nad eri nimed: Surts ja Suudsim.

JMd PR34-s (RA5) on 105 kohalikku pn. Analüüsist on välja jäetud alates 1835 sisserännanute nimed ning mõningad varem sisserännanud, kes ei kajastu Roosna-Alliku HL-s. Neist 34 ehk 32\% HL35-s ei esine. Mitmed neist esinevad PR-s lühendatud kujul (HL Kajakamae > PR Kaiakas, Ruттири $>$ Rum, Kassetael $>$ Tael jt), kuid need tuleb lugeda eri pn-ks, sest lühendamine on olnud tahtlik. Väikeste ortograafiliste erinevuste puhul on nimed loetud kattuvateks (nt HL Huint ja PR Hunt, Mihkala ja Mihkalai, Laene ja Leäne, Sursim ja Suudsim; erinevaimad samaks loetutest on Laukene ja Löok). Enamik mittekattuvatest on täiesti eri nimed, kuigi mõnikord osalise sarnasusega (HL Remmelgas ja PR Hugar, Rängisaar ja Rang, Rübe ja Naires).

JMd koguduse 1831-1835 peetud armulaualiste nimekirjas (RA7) leidub kohati erinevaid nimesid, kui need on PR34-s: Lussomäggi, aga PR34-s Lusmäe, Luss ja Lusman, Bonapart ja Pounnapart jt. Pastor on seega ka oma algset nimeloomet ümber teinud.

Osa HL nimesid võeti hiljem PR-sse üle. Näiteks oli HL35 järgi Pudruveski Villemi pn Puddrowesk, PR34 järgi aga Pudro. PR62-s (RA6) on tema pere pn juba Pudrowesk ilma märkuseta nime muutuse 
kohta. Samamoodi on HL35 Jakob Kalajöggi, PR34 Jöggi, aga PR62 Kallajöggi jt. PR-sse ei võetud siiski üle enamikku HL-s mittekattuvaid nimesid. Kui HL35-s on Mart Remmelgas ning PR34-s on ta Hugar, siis PR62-s on ta nimi jätkuvalt Hugar märkusega Hofsverz. Remmelgas 'mõisakirjas Remmelgas'. Samuti HL35-s Pärtel Kajakamäe, PR34-s Kaiakas, PR62-s Kajakas, Hofsverz. Kajakamäe. Samamoodi oli Pärtli poolvennaga (HL35 Kewitas, PR34 Kaiakas, PR62 Kajakas (Hofsverz. Kewites)).

Kuigi nimede analüüsil pole võimalik süveneda kõikide isikute andmetesse, on üldpilt siiski tajutav. Näiteks ei leidu JMd PR34-s pn-sid sellistel peredel, mis surid välja või lahkusid 1837. a-ks. HL-s pidi neil aga pn olema antud. Sel põhjusel pole mõistlik analüüsida mittekattuvust vastupidi (millised HL nimed ei esine PR-s), kuid orientiirina võib öelda, et HL 193 nimest ei leidu ei JMd ega JJn PR-s 50 nime ehk $26 \%$.

Roosna-Alliku mõisa JJn kihelkonda kuuluva osa puhul saab aluseks võtta 1842-1852 peetud PR (RA3), kuna varasemat pole säilinud. Seetõttu ei saa võrrelda neid nimesid nii täpselt kui JMd omi, kus on mõlemad allikad samast ajast. JJn PR42 sisaldab 108 pn. Neist ei leidu HL35-s seitset, kuid osa neist võivad olla sisserännanud, mida JJn PR kesise andmestiku tõttu on raske kindlaks teha. Näiteks on nendest seitsmest osa sisse rännanud pärast 1835. a JMd kogudusest (Surts, Wonter), kus sarnased nimed on olemas ning neid ei saa lugeda mittekattuvateks JJn PR42 ja HL35 vahel. Selliseid, kus JJn PR42-s on nimi tõepoolest muudetud, kohtame vaid mõnda üksikut, nt HL Heinama on PR42 Ueheinama. Järelikult kattuvad JJn PR42 ja HL35 nimed peaaegu täielikult.

Kirikuraamatutes on kokku 213 pn. Neist 28 esinevad mõlemas koguduses. Osa puhul on tegu ortograafiliste erinevustega, sh eri aluskäändega (nt JMd Errilan ja JJn Errilasse, HL Errilasse; JMd Leppatuk ja JJn Leppatok, HL Leppatuk), kuid tegu on selgelt sama nimega ning erisused pole taotluslikud, vaid tolleaegset kirjutustava arvestades tavapärased. Mõlemas koguduses esineb HL-st väikesi kirjapildi erinevusi ning ei saa öelda, et kumbki kogudus oleks lähtunud HL nimekujudest täpsemalt kui teine, st kuigi JJn pastor võttis aluseks HL nimed, ei pidanud ta tolle aja tava järgi oluliseks nende täpset kirjapilti. Eri nimesid on kahes koguduses kuni 185, mis on üsna täpselt kattuv HL nimede arvuga (ca 190). Kuni viimasena koostatud HL58-ni (RA18) ei võetud 
aga PR nimekujusid üle peale mõne üksiku erandi. Vaid HL35 Räuge ning PR34 Runge on HL50-s ja HL58-s kujul Runge ning HL35 Sibbi ja PR34 Sirp on HL50-s ja HL58-s kujul Sirbi.

Liikumise puhul ühest kihelkonnast ja kogudusest teise on pn muudetud. JJn osas sai Kajaka Hans oma perega HL35 järgi nime Kapsta. PR42-s on pere kirjas nimega Kapsta, kuid poeg Jaan, kes läks JMd kogudusse, kannab PR62-s nime Kajakas (Hofsverz. Kapsta).

Huvitavalt illustreerib Roosna-Alliku rööpnimesust JJn 1900. a koostatud PR algusesse pastori poolt kirja pandud genealoogiline skeem, „kuidas Abram Sedaviisi järeltulijad hiljem Alevi pn kandsid“. Pastor selgitab, et Abram sai küll Sedaviisi pn, kuid kohaliku kombe kohaselt (Volksgewohnheit) kutsuti teda talu järgi Alevi nimega. Abrami enne pn-de panekut surnud poja Jüri lesk aga abiellus Hindrekuga, kes tuli Alevi tallu peremeheks ning sai pn-ks Alevi. Nii Jüri kui ka Hindreku lapsed said kirikuraamatutes hiljem nime Alevi, sest see, et osa neist pidid Sedaviisi nime kandma, „oli juba unustusse vajunud“ (konnte um so eher in Vergessenheit gerathen). (RA2:4). HL58-s on Jüri lapsed veel Sedaviisi perekonnanimega, kuid JJn PR53-s (RA4) kannavad nad juba Alevi nime. „Unustusse vajumisega“ järelikult tegu pole, küll aga sooviga andmeid tegeliku nimekasutusega vastavusse viia. Kirikuraamatud kajastasidki reaalset nimekasutust HL-st paremini ning olid vastuvõtlikumad muutustele.

Roosna-Alliku puhul näeme ühe mõisa kahe eri kihelkonnas paikneva osa erinevat nimeloomet. JMd kihelkonna osas on umbes kolmandik pn-sid mõisas pandud nimedega võrreldes lühendatud või muudetud. Nende asemel võeti 1850 . a-te paiku hinnanguliselt poolte perede puhul ka PR-s kasutusele HL nimed, teiste puhul aga mitte ehk püsima jäid rööpnimed. Roosna-Alliku JJn kihelkonna osas aga kattuvad pn-d PR ja HL vahel peaaegu täielikult. Muutusi toimus isegi ühest kogudusest teise minnes, kui HL jäi nimi samaks, aga kirikuraamatutes see muudeti. HL-sse üle võetud PR nimesid on vaid 1\%. Roosna-Alliku perekonnanimede kattuvust eri allikates aastal 1835 iseloomustab joonis 2 .

Roosna-Alliku on hea näide Eestimaa kubermangust, kus ühe mõisa talupojad kuulusid kahte kirikukihelkonda. Neist ühe pastor korrastas (ilustas) mõisas pandud perekonnanimesid enda peetud kirikuraamatutes, teise pastor aga aktsepteeris neid. Mõisades pandud ehk hingeloendites esinevad perekonnanimed jõudsid mõnekümne aastaga ka kirikuraamatutesse, kuid seda vaid pooltel juhtudel. Ülejäänud 
puhkudel jäid püsima eri pn-d kahes eri arvestussüsteemis. Kirikuraamatutest hingeloenditesse jõudsid pn teised kujud vaid eranditena.

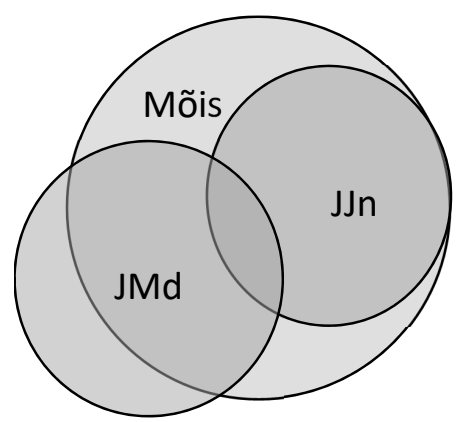

Joonis 2. Perekonnanimede kattuvus Roosna-Alliku mõisa eri osade ja allikate vahel 1835 .

\section{Rööpnimede saatus}

Prantsusmaal seati riiklikud (kirikust eraldatud) perekonnaseisuametid sisse 1792. a (Peters 1957: 807). Kuna seadus laienes ka Reinimaale, siis 1798. a-st seal perekonnaseisuregistri sisseseadmisega võis mõnedel andmetel kasutada edaspidi vaid sünnisissekande nimekuju (Genannt (bei Familiennamen)). Saksamaal fikseeriti pn kirjapilt pärast Kulturkampf'i ilmalike perekonnaseisuametite sisseseadmisega Preisimaal 1874. a ning ülesaksamaaliselt 1875. a (Kohlheim 1996: 1283, Peters 1957: 807). See võeti ka Eestis eeskujuks.

Soomes toimus rööpnimedest loobumine ning nimede korrastamine üheskoos nimede soomestamise idee tulekuga XIX-XX sajandi vahetusel ning eelkõige 1910. a-tel püüti neist lahti saada, sest tollase pn-korralduse põhimõte oli, et kodanikel oleks vaid üks ja püsiv nimi (Paikkala 2004: 537).

Riigi ja kiriku lahutamine oli Eestis teemaks juba iseseisvusaja algusest peale ning 1920. a võeti Tallinnas ja Tartus kasutusele ka ilmalikud perekonnaseisusündmuste registrid. Teiste maade eeskujul hakati tegelema ka nimede korrastamisega, kuid 1919. a pn-de muutmise seadus ei andnud selleks võimalusi.

1923. a esitas siseminister Einbund (hilisem Eenpalu) vabariigi valitsusele seaduseelnõu pn-de panemise ja muutmise kohta. Selle 
seletuskirjas mainitakse, et lisaks halvakõlaliste ja võõrapäraste nimede muutmise vajadusele on üks iseäralik nähtus olemas, mis palju segadusi sünnitab ehk rööpsed pn-d - neist üks kiriku-, teine vallakirjades. Selle tekke põhjenduseks on toodud ilmselgelt Eiseni teksti (vt ptk 2) alusel, et mõisades pandi pn 1826. a-ni, kirikuraamatutesse hakkas aga nimede kandmine pärast 1833 . [tegelikult 1832. - FP] aasta kirikuseaduse maksma hakkamist. Ümberkirjutamise juures juhtunud vigu ning tekkisid rööpsed pn-d, mis mitmeti tülikad on ja hädasti kaotamist nõuavad. (RA55:12, L 6p)

Seaduseelnõu eesmärk oli anda nimede muutmine riigikohtult siseministeeriumi alluvusse, mis võimaldaks kohapealsete komisjonide moodustamist ning seal hõlpsat nimede muutmist (RA55:14, L 7p). Riigikogu üldkomisjon ei pooldanud seaduse vastu võtmist, kuigi siseminister Einbund nimede muutmise lihtsamat korda ka riigikogu suures saalis esinedes agaralt kaitses, ning riigikogu lükkas eelnõu tagasi (II Riigikogu: IV istungjärk 1924: prot. 98 vg 22-27, lisad vg 7-14). 1930. a-ni jäi kehtima 1919. a seadus, mille järgi pn sai muuta vaid riigikohtu otsusel.

1926. a antud perekonnaseaduse juhtnöörid selgitasid, et perekonnaregistrisse kantav perekonnanimi tuleb võtta sünnisissekandest, 1930. a täpsustas kohtu- ja siseministeeriumi administratiivosakond vastuseks perekonnaseisuametniku järelepärimisele, et kui dokumentides esinevad eri pn-d, tuleb perekonnaregistrisse kandmisel aluseks võtta sünnisissekande nimi, märkides kõik teised sulgudesse (Teder 1933a: 5, Teder 1933b: 108-109). Ministeeriumi selgitusel teiste nimekujude märkimine polnud kohustuslik ning kui meetrikakande nimi oli ebaõige, võis seda parandada ministeeriumi korraldusel nimeõiendamise (st nime õigekeelsusliku parandamise) korras. Kui selline toiming polnud võimalik, võis kodanik algatada nimemuutmise (Teder 1933b: 109). Juhendite andmisel ei selgitatud aga juhtumeid, kui juba sünnikandes on kaks pn.

Tallinna perekonnaseisuametnik Edgar Rosenstrauch (hiljem Rajandi) nimetas rööpsete pn-de vahekorda lausa sõjaks, seletades nende tekke põhjust peamiselt sellega, et nimesaajad ei osanud oma mõisas saadud nime seda kirikuõpetajale üles andes välja hääldada. Lisaks tõi ta välja, et nimede segamine ja kodune muutmine /.../ saksastamise suunas kirikuraamatutes kestis iseseisvusajani välja ning nimesegadus kestab, kuni pole kõikide kodanike perekirjad korraldatud 
ja isikutunnistuste väljaandmine viidud nende alusele (Rosenstrauch 1933: 105, Rosenstrauch 1934: 120).

Ühe näite võib tuua rööpnimede kasutamisest n-ö asjaajamiskulude säästmiseks. Pn-de korraldamise seaduse (Riigi Teataja 1934, 91, 735) $\S 8 \lg 5$ määras soovi mitmest perekonnanime teisendist tarvitada ainult üht perekonnanime üle otsustamise siseministri pädevusse ning see ei käinud sama seadusega sisse viidud nimede eestistamise lihtsustatud korra alla, mis puudutas vaid nimede eestistamist (eestipäraseks muutmist) ning halvakõlaliste eestipäraste nimede muutmist. Kuna aga lihtsustatud kord oli lisaks lihtsamale asjaajamisele tasuta, kasutati seda ka rööpnimedest pääsemiseks. Nii „eestistasid“ ema AnnaHelene ja pojad Johannes-Eduard ja Alfred oma senise pn Kiisla (Juur), võttes endale uueks (!) nimeks Juur (Riigi Teataja Lisa 1935, 58, 2775; 1936, 29, 1593). Kummaline on seejuures veel asjaolu, et kui JohannesEduard oligi sünnikandes vaid Kiisla nimega (RA9:322, lk 626) ning nime võis seetõttu lugeda ühest teiseks muutmiseks - kuigi Kiisla (< kiisla 'kaerakile') polnud ei võõrapärane ega otseselt halvakõlaline -, siis Alfredi sünnikandes on vaid nimekuju Juur (RA10:57, L 52). Seetõttu puudus tal nime muutmiseks üldse juriidiline alus, kui perekirjad oleks koostatud nõude kohaselt määrata pn-ks sünnikande nimekuju. Enamasti otsustas seadust järgides kahest pn-st ühe alles jätmise siseminister ning siis ei olnud tegu tasuta toiminguga (tasuta oli koos eestistamisega muide ka perekirjade korraldamine).

Perekonnaregistrite sisseseadmisega suur osa rööpsetest pn-dest kaotati või loodi neist topeltnimed ning reeglina ametlikustati kirikuraamatutes (eelkõige sünnikandes) leiduvad nimekujud. Eeltoodud näidete varal (Kersna ja Muuga, Masing ja Romet) võib siiski öelda, et rööpseid pn-sid lõplikult kaotada ei õnnestunud, vaid nad tekitasid segadust eri dokumentides ka edaspidi.

Pn-de ühtlustamise katseid umbes sajandi (1830.-1930. aastad) vältel kujutab joonis 3. Mida tugevam joon, seda enam levinud vastav liikumissuund oli. $\mathrm{PN}=$ perekonnanimi, $\mathrm{k}=$ kirikudokumentides, $\mathrm{m}=$ mõisadokumentides, $\mathrm{v}=$ valladokumentides, $\mathrm{p}=$ riiklikes perekonnaseisudokumentides. 


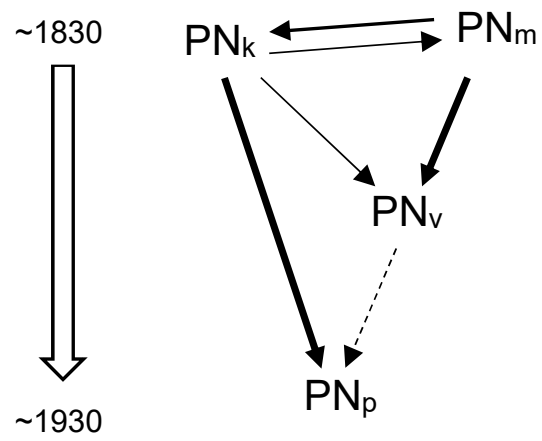

Joonis 3. Perekonnanimede liikumine eri dokumendiliikide vahel 1830.-1930. a-il.

\section{Kokkuvõte}

Rööpseid perekonnanimesid on leidunud mitmel pool maailmas, kuid vaid Lätist on teada nende sarnane tekkepõhjus - mõisas pandi 1820.-1830. a-il samale talupojale üks, kirikus aga teine perekonnanimi. Nimede panemise õigus oli mõisadel, kuid kohati võtsid pastorid osa nimede panekust või tegid seda kogu kihelkonnas korraga. Käsitletud näidetest selgub, et pastorid ja köstrid muutsid kirikuraamatutes nimesid hiljemgi ning see oli peamine rööpnimede tekke põhjus. Kui mõnel pool jõudsid kirikuraamatute nimekujud ka hingeloenditesse ning veidi sagedamini hingekirjutuse süsteemi järgmisse dokumendiliiki, vallaliikmete nimekirjadesse või linnade perekirjadesse, siis tavaline see polnud.

Nimede ortograafia ning aluskäänegi varieerusid ühe allikaliigi piires ning seda isegi samas allikas, seetõttu ei ole sageli võimalik tuvastada nime ühte ortograafiliselt täpset ,algkuju“, vaid neid on mitu.

Eestis oli üksikuid piirkondi (mõisu), kus rööpnimede hulk oli ajaloolistel põhjustel (mõisa vs kiriku arusaamad nimepanekust) suurem, nt Ahja mõisas 53\%, Roosna-Alliku mõisa Järva-Madise kihelkonna osas $32 \%$, olles enamasti aga mõne protsendi piires. Võnnu kihelkonnas on rööpnimesid hulgaliselt juurde tekitanud köster aastal 1855. Seal muutsid vastastikku üksteise nimeloomet mõisavalitsused, kolm järjestikust pastorit ning köster. Roosna-Alliku puhul tekkisid rööpnimed mõisa Järva-Madise kihelkonda kuuluvas osas, mitte aga 
Järva-Jaani kihelkonna osas. Põhjuseks oli pastorite eri arvamus mõisas pandud nimede sobivusest.

Üldise perekonnanimepanekuga loodud rööpnimedest hiljem oli XIX sajandi teisel poolel ja XX sajandi algul nende tavalisim tekkepõhjus saksastamine, harvem sugulussuhete muutumine (kärgpered, lapsendamised).

Rööpnimede tõttu oli XX sajandi algul vallavalitsuse väljaantud tsaariaegses passis või iseseisvusaegsel isikutunnistusel üks, kirikuraamatutes teine nimi, teinekord ka mõlemad. Nimede muutmine toimus seadusliku regulatsioonita, vaid mõisa-, kiriku- või vallaametniku suval.

Rööpnimede reguleerimisega hakati tegelema riiklike perekonnaregistrite sisseseadmisega alates 1926 . aastast ning suur osa rööpsetest pn-dest kaotati või loodi neist topeltnimed ning ametlikustati kirikuraamatutes (eelkõige sünnikandes) leiduvad nimekujud. Rööpnimed on dokumentides tekitanud segadust ka hiljem.

Allikaõpetuslikult näitas analüüs kirikuraamatute kohta, et neis on isikunimede püsimine ebaühtlane ning muutusi tehti üsna paindlikult. Hingeloendites olid nimed püsivamad, mis aga viis need tegelikust kasutusviisist pikapeale lahku. Liivimaa hingeloendite ees olevates nimeregistrites on osa sisus leiduvaid nimesid puudu, mida saaks arvestada onomastiliste andmebaaside koostamisel, registris esinevad nimed aga erinevad mõnikord sisus esinevatest nimedest ortograafiliselt. Rahvastikuloo, onomastika jm uurimisel peab arvestama hingeloendite ja kirikuraamatute andmete võrdlemisel nii territoriaalsete erisuste (sh mõisakobarate) kui ka isikuandmete mittekattuvusega.

\author{
Aadress: \\ Fred Puss \\ Ajaloo ja arheoloogia instituut, arhiivinduse osakond \\ Tartu Ülikool \\ Jakobi 2-222 \\ 51014 Tartu, Eesti \\ E-post: fred@isik.ee
}




\section{Allikad}

EKI KN. Eesti Keele Instituudi kohanimekartoteek. <http://heli.eki.ee/kohanimed/>. Vaadatud 25.09.2019.

ELK.18.0.8. Põlva koguduse surmameetrika (koguduse kantseleis). 1939-1971.

ELK.18.0.11. Põlva koguduse personaalraamat (koguduse kantseleis). 1927-.

Haudi. Kalmistute register. <https://www.kalmistud.ee>. Vaadatud 25.09.2019.

LBV = Liefländische Bauer-Verordnung. St. Petersburg (1819).

LMS = Oldekop, Gustav Adolph ja Ludwig Wilhelm Moritz, tlk (1820) Liiwlandi Marahwa Säedus. Tartu.

LTS = Masing, Otto Wilhelm, tlk (1820) Lihwlandi-ma Tallorahwa Seädus. EssimenneKolmas jaggu. Tartu: J. C. Schünmann.

Onomastika. Eestlaste perekonnanimed. Koostanud Aadu Must. <http://www.ra.ee/ apps/onomastika/>. Vaadatud 25.09.2019.

RA1 ${ }^{4}=$ EAA.1214.1.162. Keila koguduse sünnimeetrika. 1857-1880.

RA2 = EAA.1233.1.110. Järva-Jaani koguduse personaalraamat. 1900-1938.

RA3 = EAA.1233.1.88. Järva-Jaani koguduse personaalraamat. 1842-1852.

RA4 = EAA.1233.1.91. Järva-Jaani koguduse personaalraamat. 1853-1863.

RA5 = EAA.1234.1.138. Järva-Madise koguduse personaalraamat. 1834-1843.

RA6 = EAA.1234.1.143. Järva-Madise koguduse personaalraamat. 1862-1891.

RA7 = EAA.1234.1.15. Järva-Madise koguduse armulaualiste nimekiri. 1821-1852.

RA8 = EAA.1248.1.29. Ambla koguduse sünnimeetrika. 1835-1848.

RA9 = EAA.1255.1.526. Kambja koguduse sünnimeetrika. 1892-1906.

RA10 = EAA.1255.1.527. Kambja koguduse sünnimeetrika. 1907-1913.

RA11 = EAA.1257.1.311. Kursi koguduse personaalraamat. 1861-1930.

RA12 = EAA.1266.1.64. Äksi koguduse personaalraamat. 1830-1839.

RA13 = EAA.1269.1.796. Räpina koguduse personaalraamat. 1816-1851.

RA14 = EAA.1864.2.VIII-147. Ambla kihelkonna perekonnanimede andmise raamat. 1835.

RA15 = EAA.1864.2.VIII-151. Järva-Jaani kihelkonna perekonnanimede andmise raamat. 1835.

RA16 = EAA.1864.2.VIII-174. Kullamaa kihelkonna perekonnanimede andmise raamat. 1835.

RA17 = EAA.1864.2.IX-118. Järva-Jaani kihelkonna hingeloendid. 1850.

RA18 = EAA.1864.2.X-239. Järva-Jaani kihelkonna hingeloendid. 1858.

$4 \quad$ RA $=$ Rahvusarhiiv, TLA = Tallinna Linnaarhiiv. Arhiivimaterjalid on esitatud viitekoodi järjekorras. Numbrilise lühendita on loetletud allikad, millest on saadud tekstis viitamata andmeid (sh üldistuse jaoks). Kui tekstis esinevas viites puudub lehenumber (L) või leheküljenumber (lk), on säilik pagineerimata. Kui viites leidub koolon, on säilik digiteerituna kasutatav rahvusarhiivi digikogus Saaga (www.ra.ee/dgs/) ning kooloni järel on toodud digiversiooni kaadrinumber. Säilikute kohta on esitatud kokkuvõtlik pealkiri ning piirdaatumid. Säiliku täpsemaid andmeid saab viitekoodi järgi arhiiviinfosüsteemist https://ais.ra.ee/. 
RA, EAA.1865. Võnnu kihelkonna hingeloendid. 1826-1858.

RA19 = EAA.1865.2.31/6. Puurmani mõisa hingeloend. 1858.

RA20 $=$ EAA.1865.2.34/2. Laiuse mõisa hingeloend. 1826.

RA21 = EAA.1865.2.71/6. Ruusa mõisa hingeloend. 1826.

RA22 = EAA.1865.5.15. Elistvere mõisa hingeloend. 1826.

RA23 = EAA.1996.1.57. Võnnu-Kärsa õigeusu kogudusse kuuluvate Rasina valla õigeusklike nimekiri. 1888-1891.

RA24 = EAA.2434.1.114. Laiuse koguduse personaalraamat. 1823-1828.

RA25 = EAA.2434.1.115. Laiuse koguduse personaalraamat. 1830-1836.

RA26 = EAA.2434.1.117. Laiuse koguduse personaalraamat. 1835-1840.

RA27 = EAA.2623.1.235. Tartu linna kodanike perekirjad. 1901.

RA28 = EAA.2623.1.237. Tartu linna kodanike perekirjad. 1903.

RA29 = EAA.30.1.4030. Toimik kindralkuberneri korraldusest talupoegadele perekonnanimede paneku kohta. 1834-1838.

RA30 = EAA.314.1.459. Tartu väeteenistuskomisjoni kutsealuste nimekiri. 1895.

RA31 = EAA.3147.1.217. Põlva koguduse sünnimeetrika. 1892-1900.

RA32 = EAA.3147.1.235. Põlva koguduse personaalraamat. 1911-1930.

RA33 = EAA.3147.1.244. Põlva koguduse kirikutähed. 1851-1860.

RA34 = EAA.3148.1.146. Tartu Maarja koguduse personaalraamat. 1883-1901.

RA35 = EAA.3150.1.719. Tartu Peetri koguduse personaalraamat. 1871-1923.

RA, EAA.3172. Võnnu koguduse meetrikaraamatud. 1711-1926.

RA36 = EAA.3172.1.98...102. Võnnu koguduse personaalraamatud. 1806-1839.

RA37 = EAA.3172.1.103. Võnnu koguduse personaalraamat. 1842-1855.

RA38 = EAA.3172.1.104. Võnnu koguduse personaalraamat. 1842-1855.

RA39 = EAA.3172.1.108. Võnnu koguduse personaalraamat. 1842-1855.

RA40 = EAA.3172.1.105...107. Võnnu koguduse personaalraamatud. 1855-1871.

RA, EAA.3172.1.109...112. Võnnu koguduse personaalraamatud. 1871-1888.

RA, EAA.3172.1.127...132. Võnnu koguduse personaalraamatud. 1889-1939.

RA41 = EAA.3172.1.52. Võnnu koguduse meetrikaraamat. 1891.

RA42 = EAA.3172.1.85. Võnnu koguduse sünnimeetrika. 1863-1874.

RA43 = EAA.3172.3.279. Võnnu koguduse pastori missiiv. 1818-1829.

RA44 = EAA.3213.1.163. Rasina vallaliikmete nimekiri. 1875-1890.

RA45 = EAA.3213.1.172. Rasina vallaliikmete nimekiri. 1916.

RA46 = EAA.3213.1.180. Rasina vallaliikmete nimekiri. 1911-1915.

RA47 = EAA.3258.1.189. Ahja vallaliikmete nimekiri. 1873-1875.

RA48 = EAA.3258.1.194. Ahja vallaliikmete nimekiri. 1888-1891.

RA49 = EAA.3265.1.14. Kastre-Võnnu vallaliikmete nimekiri. 1899-1916.

RA50 = EAA.T-451.2.1171. Karl Romet-Masingu pärimistoimik. 1972.

RA51 = ERA.28.2.5525. Jaan Muuga-Kersna opteerimistoimik. 1920.

RA52 = ERA.2943.1.293. Rasina vallaelanike nimekiri. 1927-1939.

RA53 = ERA.2943.1.44. Rasina vallaelanike nimekiri. 1919-1925.

RA54 = ERA.2943.1.597. Rasina vallavalitsuse kirjavahetus Tartu Maavalitsusega valla

piiride muutmise asjus koos elanike nimekirjadega. 1938-1939. 
RA55 = ERA.31.3.2593. Siseministri esitatud perekonnanimede panemise ja muutmise seaduse eelnõu. 1923.

RA56 = ERA.4414.2.2075. Ahja valla elanike nimekirjad. 1939.

RA 57 = ERA.5320.1.814. Põlva rajooni surmaaktide tähestikuline register. 1961-1970.

RA58 = ERA.5320.1.815. Põlva rajooni surmaaktide tähestikuline register. 1971-1980.

RA59 = ERA.5320.1.836. Ahja (endise Rasina) valla perekonnaregister. 1926-1949.

RA60 = ERA.5320.1.845. Ahja valla perekonnaregister. 1926-1949.

II Riigikogu: IV istungjärk (1924) II Riigikogu: IV istungjärk: [29. apr. - 6. juuni 1924]: protokollid nr. 98-114. Tallinn: Riigikogu.

Riigi Teataja. Tallinn: Kohtuministeerium. 1918-1940.

Riigi Teataja Lisa. Seaduste alustel avaldatud teadaanded. Tallinn: Kohtuministeerium. 1921-1940.

TLA1 = TLA.1359.2.21. Tallinna Kaarli koguduse personaalraamat. 1874-1907.

TLA2 = TLA.1359.2.31. Tallinna Kaarli koguduse sünnimeetrika. 1915-1922.

TLA3 = TLA.1463.1.12. Tallinna Pühavaimu koguduse personaalraamat. 1904-1917.

TLA4 = TLA.1483.1.111. Tallinna linna perekonnaregister. 1926-1949.

TLA5 = TLA.1483.1.120. Tallinna linna perekonnaregister. 1926-1949.

TLA6 $=$ TLA.1483.1.173. Tallinna linna perekonnaregister. 1926-1949.

TLA7 = TLA.1483.1.195. Tallinna linna perekonnaregister. 1926-1949.

TLA8 = TLA.1483.1.430. Tallinna linna perekonnaregistri alusdokumendid. 19261949.

TLA9 $=$ TLA.168.1.572. Toompea kogukonna elanike perekonnakirjad. 1906-1908.

TLA10 = TLA.236.2.29. Tallinna Oleviste koguduse personaalraamat. 1905-1929.

TLA11 $=$ TLA.31.1.58. Tallinna Niguliste koguduse leeritatute register. 1878-1903.

\section{Kirjandus}

Annist, Sirje (1971) „O zaselenii prixoda Rjapina v XVI-XVII v.“. Sel'skie poselenija Pribaltiki (XIII-XX vv.). Sbornik statej, 13-27. Moskva: Institut ètnografii im. N. N. Mikluxo-Maklaja.

Bach, Adolf (1978) Deutsche Namenkunde. I, 2: Die deutschen Personennamen. 3., unveränderte Aufl. Heidelberg: Carl Winter Universitätsverlag.

Eisen, Matthias Johann (1921) „Sugunimede tekkimine“. Eestlasele eesti nimi, 9-15. (Akadeemilise Emakeele Seltsi Toimetused, 2.) Tartu.

Eisenberg Davis, Lauren B. (1996) „Alternate Surnames in Russian Poland“. ZichronNote 16, 4, 5-6.

Elgenstierna, Gustaf, ed. (1925) Den introducerade svenska adelns ättartavlor med tillägg och rättelser. I, Abrahamsson-Celsing. Stockholm: P. A. Norstedt \& Söner.

Fejsa, Mihajlo P. (2013) „Ruthenian Family Names in Serbia“. American Journal of Linguistics 2, 2, 28-31.

Genannt (bei Familiennamen) - GenWiki. Saadaval Internetis $<$ http://wiki-de.genealogy.net/Genannt_(bei_Familiennamen)>. Vaadatud 27.02.2020.

Geyh, Patricia Keeney, Joyce Soltis Banachowski and Linda Boyea (2002) FrenchCanadian sources: a guide for genealogists. Orem, Utah, USA: Ancestry Publishing. 
Hanks, Patrick W. (2003) „Americanization of European family names in the seventeenth and eighteenth centuries“. Onoma 38, 119-154. https://doi.org/10.2143/ ONO.38.0.2002556

Henno, Kairit (2000) Eesti priinimed: Jaani kihelkond. Tallinn: Eesti Keele Sihtasutus. Heydenreich, Eduard (1913) Handbuch der praktischen Genealogie, I. und II. Band. Leipzig: H. A. Ludwig Degener.

Kahk, Juhan (1969) Die Krise der feudalen Landwirtschaft in Estland. Das zweite Viertel des 19. Jahrhunderts. Tallinn: Eesti Raamat.

Kallasmaa, Marja, Udo Uibo ja Peeter Päll (2017) „Eesti perekonnanimeraamatust“. Keel ja Kirjandus 12, 926-938.

Keem, Hella (1970) Tartu murde tekstid. (Eesti murded, 3.) Tallinn: Valgus.

Kohlheim, Rosa (1996) „Entstehung und geschichtliche Entwicklung der Familiennamen in Deutschland“. Rmt. Ernst Eichler et al., Hrsg. Namenforschung: ein internationales Handbuch zur Onomastik = Name studies: an international handbook of onomastics = Les noms propres: manuel international d'onomastique, vol. 2, 1280-1284. (Handbücher zur Sprach- und Kommunikationswissenschaft.) BerlinNew York: Walter de Gruyter.

Kotilainen, Sofia (2011) „The genealogy of personal names: towards a more productive method in historical onomastics“. Scandinavian Journal of History 36, 1, 44-64. https://doi.org/10.1080/03468755.2010.542661

Kruus, Hans (1930) Talurahva käärimine Lõuna-Eestis XIX sajandi 40-ndail aastail. Tartu: Eesti Kirjanduse Selts.

Lemoine, Bertrand (1988) Gustave Eiffel. Basel, Boston und Berlin: Birkhäuser.

Liitoja, Ülle (1992) „Põhja-Tartumaa talunimedest“. Uurimusi Läänemeremaade ajaloost 7, 36-49. (Tartu Ülikooli Toimetised, 941.) Tartu: Tartu Ülikool.

Loos, Wolfgang (1973) „Die 'Versteinerung' der Familiennamen im früheren Fürstentum Lippe“. Lippische Mitteilungen Aus Geschichte Und Landeskunde 42, 91-115.

Must, Aadu (2000) Eestlaste perekonnaloo allikad. 2., parand. ja täiend. tr. Tartu: Ajalookirjanduse Sihtasutus „Kleio“.

Mühlendahl, Ernst von und Heiner von Hoyningen gen. Huene, Bearb. (1973) Die Baltischen Ritterschaften: Übersicht über die in den Matrikeln der Ritterschaften von Livland, Estland, Kurland und Oesel verzeichneten Geschlechter. 2., verbesserte und erweiterte Aufl. (Aus Dem Deutschen Adelsarchiv, 4.) Limburg/Lahn: Starke.

Paikkala, Sirkka (2004) Se tavallinen Virtanen. Suomalaisen sukunimikäytännön modernisoituminen 1850-luvulta vuoteen 1921. (Suomalaisen Kirjallisuuden Seuran Toimituksia, 959.) Helsinki: Suomalaisen Kirjallisuuden Seura.

Peters, Hans, ed. (1957) Handbuch der kommunalen Wissenschaft und Praxis. Zweiter Band: Kommunale Verwaltung. Springer-Verlag.

Puss, Fred (2016) „Perekonnanimede uurimise piirkondlikke eripärasid“. Oma Keel 1, $30-38$.

Rajandi, Edgar ja Helmut Tarand (1966a) „Perekonnanimedest ja nende uurimise ülesannetest". Keel ja Kirjandus 4, 226-231.

Rajandi, Edgar ja Helmut Tarand (1966b) „Meie perekonnanimede liigitamisest ja seletamisest“. Keel ja Kirjandus 7, 393-402. 
R[eiman], V[illem] (1898) „Haridusloolised pildid IX. Kuidas meile priinimed pandi [1.-3.]“. Postimees. Tartu, nr 70-72, 26.-28.03.1898.

Rosenberg, Tiit (2010) „Talurahva lindpriiuse ajajärk“. Eesti ajalugu. V. Pärisorjuse kaotamisest Vabadussõjani, 71-80. Toim. Andres Andresen jt. Tartu: Ilmamaa.

Rosenstrauch, Edgar (1933) „Nimeõigusest“. Linnad ja Alevid 7, 102-106.

Rosenstrauch, Edgar (1934) „Nimeõigusest. (Järg)“. Linnad ja Alevid 6, 116-121.

Ryman, Lennart (2002) Salanus, Tunström och Sporrong. Tillnamnsbruk och framväxten av släktnamn i Uppland. (Anthroponymica Suecana, 13.) Umeå: Umeå universitet.

Saar, Evar (1999) „Inemisenimmi ja kotussõnimmi läbikasumisest Räpinä kihlkunnan“. Rmt. Karl Pajusalu ja Tõnu Tender, toim. Õdagumeresoomõ veeremaaq. Läänemeresoome perifeeriad. Konverents Kurgjärvel, rehekuu 29.-31.[10.]1998, 80-92. (Võro Instituudi toimõtiseq, 6.) Võro: Võro Instituut.

Saar, Evar (2008) Võrumaa kohanimede analüüs enamlevinud nimeosade põhjal ja traditsioonilise kogukonna nimesüsteem. (Dissertationes philologiae Estonicae Universitatis Tartuensis, 22.) Tartu: Tartu Ülikooli Kirjastus.

Saar, Evar (2019) „Räpina perekonnanimed ja lisanimed“. Emakeele Seltsi aastaraamat 64, 205-231. https://doi.org/10.3176/esa64.08

Solin, Heikki (2017) „Onomastics“. Rmt. Paul Corby Finney, ed. The Eerdmans encyclopedia of early Christian art and archaeology. Vol 2, K-Z., 247-254. Grand Rapids, Michigan: Wm B. Eerdmans Publishing Co.

Statina, Natal'ja Vladimirovna (2010) „Dinamika formuljara metričeskix knig 17861919 gg. (po arxivnym materialam)“. Vestnik Permskogo universiteta. Rossijskaja i zarubežnaja filologija 4, 17-22.

Tannberg, Tõnu (2010) „Tsaariaegne sõjaväekohustus Pärnumaal“. Rmt. Aldur Vunk, peatoim. Pärnumaa 2, 149-162. Tallinn: Eesti Entsüklopeediakirjastus.

Tarkiainen, Ülle (2000) Hajatalud ja külad Põhja-Liivimaal 17. sajandil. (Scripta Archivi Historici Estoniae.) Tartu: Eesti Ajalooarhiiv.

Teder, Teofil (1933a) „Isiku perekonnanimede, nimede ja kohanimede kirjutusviisist“. Linnad ja Alevid 1, 5-12.

Teder, Teofil (1933b) „Vastuseks V. Avesson'i artiklile 'Veel isikunimede, nimede ja kohanimede kirjutamisviisist”". Linnad ja Alevid 7, 108-111.

Teder, Teofil (1939) Perekonnaseisuametniku käsiraamat. Tallinn: Siseministeeriumi Administratiiv-ala Kirjastus.

Tiik, Leo (1987) „Perekonnanimede panekust Eestimaa talurahvale 1835. aastal“. Keel ja Kirjandus 2, 83-88.

Utterström, Gudrun (1985) Släktnamn. Tillkomst och spridning i norrländska städer. (Kungl. Skytteanska Samfundets Handlingar, 29.) Umeå: Kungl. Skytteanska Samfundet.

Wenzel, Walter (2004) „Familiennamen“. Rmt. Andrea Brendler und Silvio Brendler, Hrsg. Namenarten und ihre Erforschung: Ein Lehrbuch für das Studium der Onomastik. Anlässlich des 70. Geburtstages von Karlheinz Hengst, 705-742. (Lehr- und Handbücher zur Onomastik, 1.) Hamburg: Baar. 


\begin{abstract}
Fred Puss: Muuga or Kersna? The appearance and perishment of Estonian parallel family names. The reason for the appearance of parallel family names in Estonia and Latvia is unique: in the 1820s-1830s, the manor officials gave family names to local peasants and the Lutheran pastors changed those names or gave different ones. In some areas, mismatch was up to $53 \%$, but generally did not exceed a few percent. Sometimes in the church records, the names were later changed to match the manor (or later tax) records, but much less often vice versa. However, when the names in the church records were changed (mostly Germanized) in the second half of the 19th century, but not in the tax records, new mismatches appeared. As of 1926, the state began to keep vital statistics records and the name in a birth entry in the church book was usually fixed as the only family name thereafter. This marked the end of the occurrence of most of the parallel family names in Estonia, but some became double family names and some still caused confusion in later records.
\end{abstract}

Keywords: anthroponomastics, family names, Estonia, parallel names, church records, tax records 